\title{
Graptolites of the Králův Dvưr Formation (mid Katian to earliest Hirnantian, Czech Republic)
}

\author{
Petr Kraft, Petr Štorch \& Charles E. Mitchell
}

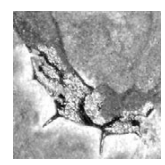

\begin{abstract}
Ten graptolite species have been recognized by a general revision of all the material (both historical and new) collected from the Králův Dvůr Formation of the Prague Basin. One species belongs to the dicranograpid genus Dicellograptus and the remaining are biserial taxa assigned to the diplograptid genera Diplograptus and Anticostia, the lasiograptids Paraplegmatograptus and Phormograptus, the climacograptid Styracograptus, and the neodiplograptid genera Normalograptus and Metabolograptus. Although graptolite specimens are rare in these strata, there does appear to be a regular succession among the species, which results in a relatively low diversity of graptolites throughout the formation. The maximum species diversity is in the upper part preceding the distinct carbonate Perník Bed sedimentation. Three of the four species that occur in the lower part of the formation are endemic to the study region, however, Anticostia teres occurs in P. linearis Zone strata in Baltica (Bornholm and Sweden). Three of the four species that occur in the middle and upper part of the unit are more widely distributed species that occur also in the late Katian of the paleotropics. The uppermost Králův Dvůr Formation is marked by impoverishment that reduced the fauna to a single cosmopolitan species that occupies a narrow interval below the first early Hirnantian diamictite. This graptolite distribution pattern appears to reflect changing global environmental conditions, including a late Katian climate amelioration (with expanded geographic ranges of several paleotropical graptolite species) followed by cooling and climate deterioration during latest Katian and early Hirnantian interval. Based on the new data, a biostratigraphic scheme has been modified and the Králův Dvůr Formation is inferred to be of mid Katian (P. linearis) to the earliest Hirnantian (early M. extraordinarius) age. - Key words: graptolite, Ordovician, Katian, Hirnantian, Prague Basin, biostratigraphy.
\end{abstract}

Kraft, P., ŠToRCh, P. \& Mitchell, C.E. 2015. Graptolites of the Králův Dvůr Formation (mid Katian to earliest Hirnantian, Czech Republic). Bulletin of Geosciences 90(1), 195-225 (13 figures, 5 tables). Czech Geological Survey, Prague. ISSN 1214-1119. Manuscript received March 27, 2013; accepted in revised form November 5, 2014; published online January 19, 2015; issued January 26, 2015.

Petr Kraft, Institute of Geology and Palaeontology, Faculty of Science, Charles University in Prague, Albertov 6, 12843 Praha 2, Czech Republic; kraft@natur.cuni.cz・Petr Štorch, Institute of Geology v.v.i., Academy of Sciences of the Czech Republic, Rozvojová 269, 16500 Praha 6, Czech Republic; storch@gli.cas.cz・Charles E. Mitchell, Department of Geology, University at Buffalo-SUNY, Buffalo, NY 14260-3050, USA; cem@ geology.buffalo.edu

Graptolite faunas are rare to absent in the majority of the Upper Ordovician successions of north-western periGondwana. An exception within this graptolite "desert" is the middle Katian to lowermost Hirnantian graptolites of the Králův Dvůr Formation (Prague Basin, Barrandian area, central Bohemia, Fig. 1). Generally rare but locally common biserials and dicellograptids were discovered in this area in mid- $19^{\text {th }}$ century. Barrande (1870, p. 126, Diplograptus teres, nomen nudum) first noted their presence in association with his investigations at the historical Lejškov locality (Fig. 1) and his concept of "colonies". Dicellograptus anceps (=D. laticeps herein) was mentioned by Marr (1880). All graptolite material from the $19^{\text {th }}$ century, including Barrande's collection but excluding collections by J. Schary, was subsequently described in a monograph by Perner (1895). Until Přibyl's (1949) revision of biserial taxa, only a few notes on the stratigraphic occurrences of the faunas were published. The most recent systematic revision of graptolites from the Králův Dvůr Formation (Štorch 1989) focused exclusively on the upper part of the formation. The present paper benefits from substantial recent progress in the general knowledge of taxonomy and systematics of the Upper Ordovician graptoloids (Chen et al. 2005, Mitchell et al. 2007, Mitchell et al. 2009, Melchin et al. 2011, Štorch et al. 2011). Here we re-examine all available specimens of graptoloids from the Králův Dvůr Formation, including a number of new collections, in an effort to bring these occurrences to broader attention, to up-date their taxonomic treatment and refine the biostratigraphic and biogeographic relationships of the fauna in the light of these revisions. We do not include rare dendroids Ptilograptus sp. and Callograptus sp. also known from this unit (unpublished fragments and Havlíček \& Vaněk 1966). 


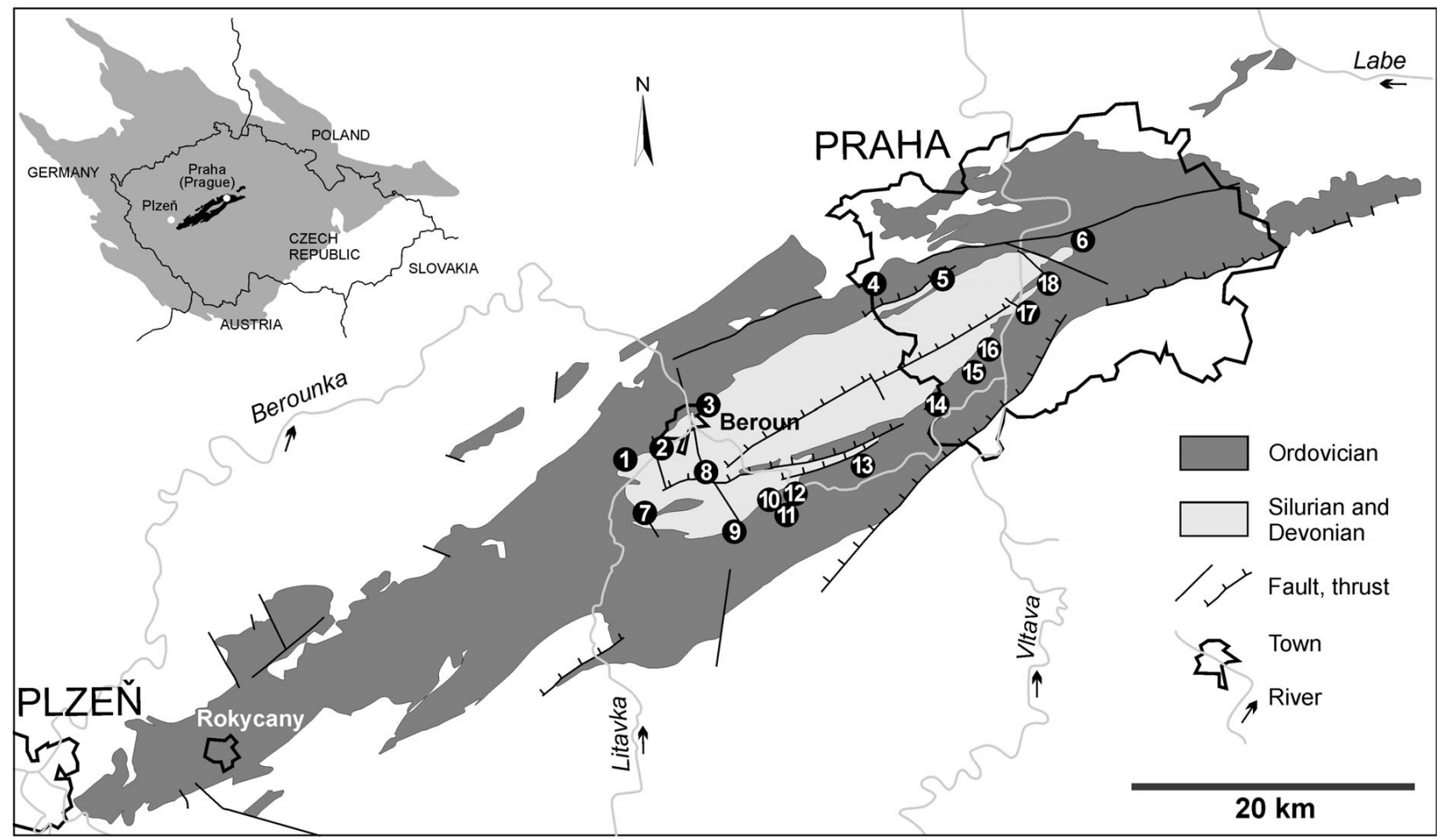

Figure 1. Sketch map of the Prague Basin relic and localities mentioned in the text. Location of the Prague Basin on the territory of the Czech Republic and the Bohemian Massif (grey) in top left corner. 1 - Levín - slope above the highway, 2 - Králův Dvůr (historical localities Králův Dvůr = Königshof and Kosov), 3 - Vráž - D5 highway exit 14, 4 - Praha-Zličín - housing estate (section in construction site), 5 - Praha-Malá Ohrada - housing estate (section in construction site), 6 - Praha-Vršovice - Eden (construction site), 7 - Lejškov near Málkov, 8 - Tobolka near Koněprusy - borehole, 9 - Nesvačily - well excavation, 10 - Liteň - railway cut, 11 - Svinaře - N of the village (cut of Svinaře Brook), 12 - Zadní Třebaň - railway cut, 13 - Karlík hillslope NE of the village, 14 - Praha-Radotín - cut of the road to Třebotov, 15 - Praha-Radotín - highway tunnel, 16 - Praha-Velká Chuchle - slope above the hippodrome, 17 - Praha-Braník - Pod Zemankou Street, 18 - Praha-Nusle (old material without exact localization).

\section{Geological and palaeontological settings}

The Upper Ordovician Králův Dvůr Formation crops out in a belt that surrounds the Silurian to Middle Devonian core of the Prague Basin volcano-sedimentary infill (Fig. 1). The Králův Dvůr Formation was also encountered in several boreholes in the central part of the basin relic below the overlying systems (e.g. in Tobolka near Koněprusy and Praha-Ořech). A prominent change in sedimentation, traceable across the whole "Mediterranean Province" (Havlíček 1989), can be observed at the base of the formation where the black shale lithofacies of the underlying Bohdalec Formation (Fig. 2) is replaced by greyish to greenish shales with micritic carbonate nodules. A prominent faunal change also occurs at this level: the Aegiromena-Drabovia brachiopod fauna of underlying units is replaced by lowdiversity associations assigned to the relatively deep-water and soft-bottom Foliomena Fauna.

A complete list of fossil taxa of the Králův Dvůr Formation (e.g. Havlíček \& Vaněk 1966) indicates that this interval records one of the more diverse fossil assemblages recovered from any formation of the Bohemian Ordovician. The fauna is dominated (roughly in order of decreasing species diversity) by benthos such as trilobites, bivalves, rhynchonelliform brachiopods, gastropods, ostracods, echinoderms, hyolithids, linguliform brachiopods, conulariids and others. The stratigraphic distribution of fossils is highly irregular and patchy, however, and portions of the formation are distinct both paleogeographically and stratigraphically. Based on those differences and typical species of trilobites and brachiopods, several faunal associations have been defined and described by Budil et al. (2011b).

The Králův Dvůr Formation is 25-200 m thick (Havlíček 1981, fig. 15; Havlíček in Chlupáč et al. 1998), and is composed of monotonous, commonly bioturbated shales. Their greyish to greenish color reflects a low content of organic matter (total organic $\mathrm{C}$ usually ranges between 0.1 and $0.3 \%$ ). In the uppermost part of the formation, a carbonate-rich, 5-20 cm thick mudstone layer is developed in the great majority of sections (clayey carbonate according to Havlíček in Chlupáč et al. 1998). The overall faunal diversity increases abruptly in this level. Because of its correlative potential and specific fossil content, Brenchley \& Štorch (1989) formalized the local jargon name, "Perník Bed" (i.e. gingerbread bed), for this 


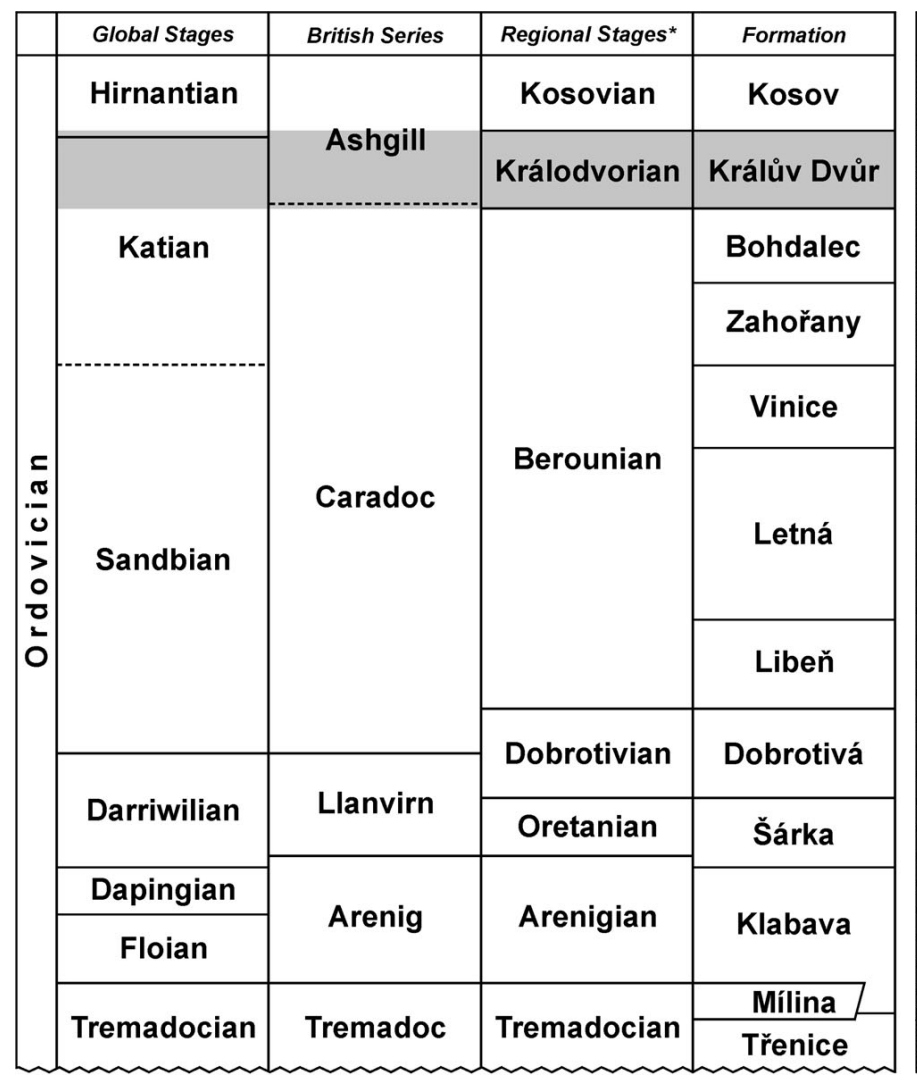

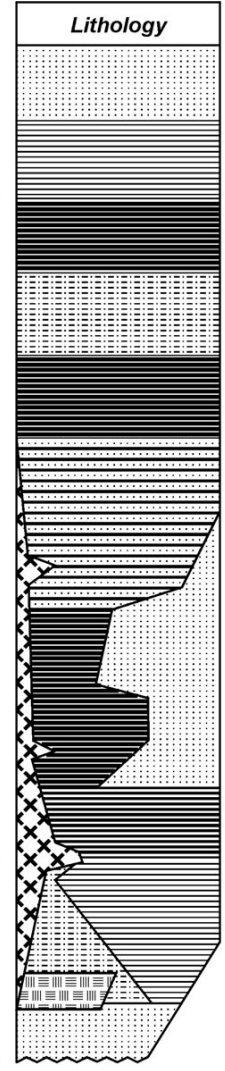

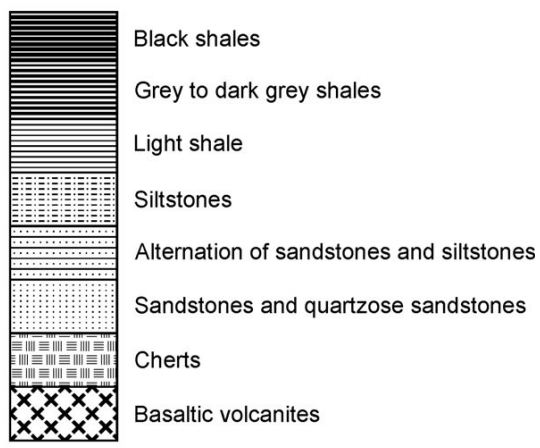

Figure 2. Stratigraphy and simplified lithology of the Ordovician in the Prague Basin and its general correlations. British (Avalonian) series were used as basic chronostratigraphic units in the Prague Basin until Havlíček \& Marek (1973) established regional ones. (*)They were defined as series but have been used as stages together with British units handled the same way. distinctive layer. The Perník Bed is overlain by $0.3-6 \mathrm{~m}$ of shale at the top of the Králův Dvůr Formation (Štorch \& Mergl 1989), below the lower diamictite bed, which marks the base of the Kosov Formation (Fig. 3). Above the Perník Bed the overall faunal diversity decreased dramatically in response to global climatic changes driven by early Hirnantian glaciation.

\section{Preservation of graptolites}

Rhabdosome preservation ranges from completely flattened to almost full-relief. In flattened specimens some internal structures, such as the nema, lists or rods are often visible, pressed through the thecal walls. In moderately flattened rhabdosomes with three-dimensionally preserved external structures, some internal structures are discernable. Rhabdosome walls are generally well preserved (fusellar rings are evident in some specimens) but easily flake off in weathered material. In all the degrees of flattening rhabdosomes may be more or less distorted due to irregular soft-sediment distortion. Some rhabdosomes are bent or twisted non-parallel to bedding. Depending on the orientation of compression, i.e. position of specimens in the sediment, different features are affected. Besides usual lateral flattening, scalariform, sub-scalariform and box-flattened (a special case of lateral flattening in which one lateral surface of the rhabdosome and one apertural surface is in profile while the other apertural surface is presented in scalariform view) preservation is common. Some flattened rhabdosomes were identified to be aseptate because of the style of distortion in the proximal-distal direction. Most species show some preferential type of flattening, usually perpendicular to the broadest cross section of rhabdosome (i.e. the profile with maximal hydrodynamic drag). In the case of rhabdosomes that are elliptic or nearly circular in cross section (e.g., Normalograptus angustus), there is no preferential orientation to the bedding plane. $\mathrm{Pu}-$ rely obverse or reverse profile views of rhabdosomes of these species are rare and sub-scalariform or scalariform orientations predominate. This is why the number of specimens appropriate for biometric study is low in N. angustus compared to the amount of collected material of this common species.

\section{Stratigraphy and correlations}

There are no known continuous sections through the Králův Dvůr Formation. The ranges of graptolites, shown in Fig. 3, are inferred from partial sections compiled over all accessible localities. Thus, the composite section through the formation is tentative and illustrates our current knowledge on the species co-occurrence and succession. The 
lower part of formation is less well known than the upper part where more data are available and thus reliability of the proposed results (e.g. stratigraphic chart and diversity analyses) for that interval is much higher. Detailed reconstruction of the succession is further biased by lateral changes in biofacies and shale lithology. In spite of those restrictions, the new data presented here justify the revision and formal re-definition of the previous graptolite biostratigraphy of the Králův Dvůr Formation.

There have been several previous attempts to establish a biostratigraphic subdivision of the Králův Dvůr Formation strata based on graptolites. Bouček (1928) mentioned that Dicellograptus anceps (= D. laticeps herein) is frequent in the upper part of the formation, and Diplograptus teres (= Anticostia teres herein) and Diplograptus lobatus (Bouček appears to have included several species within this name) occur in the lower part. In his stratigraphic table, Bouček (1928) used only " $D$. anceps" as an index species and thus he considered the whole of the formation to belong to that single graptolite zone, with direct correlations to Scotland and Sweden where D. anceps was used as an index species. Bouček's (1928) conception of a single graptolite zone through the entire Králův Dvůr Formation was adopted by other authors such as Přibyl (1949), Havlíček \& Vaněk (1966) and Havlíček \& Marek (1973). In contrast, Chlupáč (1951a, b, 1953), concluded from his study of several localities in the south-eastern flank of the outcrop belt that the Králův Dvůr Formation contained a succession of several faunally distinct "horizons". In the upper part of the formation, below the Perník Bed, he recognized an interval characterized by the occurrence of "Climacograptus angustus". In the uppermost beds of the formation Chlupáč (1951a, 1953) reported a very rich fauna that he said was characterized by the common occurrence of "Glyptograptus teres" concentrated in the layer just above the Perník Bed ("pelocarbonatic intercalation" according to Chlupáč 1951a). His detailed descriptions of the localities (Zadní Třebaň and Liteň) and the graptolite occurrences (see below), however, clearly indicate that the graptolite species that he had in these collections was Metabolograptus ojsuensis. Earlier misidentification and consequent extension of the stratigraphic range of "Glyptograptus teres" led Havlíček \& Vaněk (1966) to recognize but a single biozone in the Králův Dvůr Formation. Subsequently, apparently because of his revised understanding of Anticostia teres and the stratigraphic position of the Lejškov locality, Havlíček in Chlupáč et al. (1992) returned to a stratigraphical concept similar to that of Bouček (1928) with a lower Glyptograptus teres Zone and an upper Dicellograptus anceps Zone. At around the same time, Storch \& Mergl (1989) studied the upper part of the formation and noted that it was difficult to form a detailed graptolite biostratigraphy for the unit. They kept the concept of informal "horizons" and distinguished the "Clima- cograptus angustus Horizon" in the lower portion of the upper Králův Dvůr Formation and a separate "Glyptograptus aff. teres Horizon" within the uppermost portion of the formation. This model also was adopted by Štorch (1989) who reassigned G. aff. teres material to Glyptograptus cf. ojsuensis. Havlíček in Chlupáč et al. (1998) critically synthesized all previous concepts into a stratigraphic chart in which he used a succession of three loosely defined zones: "Glyptograptus teres" in the lower part, "Scalarigraptus angustus" in the middle part, and "Glyptograptus cf. ojsuensis" in the uppermost part of the formation. This informal zonation is further updated and refined herein.

In the lower part of the Králův Dvůr Formation no well-defined biozone can be established due to the scarcity of graptolite data and sufficiently exposed sections. Several graptolite species occur in this part of the formation but specimens are rare and, for the most part, have been collected from different, isolated localities. Thus, it is not possible to establish their stratigraphic relationships. An informal interval with Anticostia teres and Styracograptus lobatus (Fig. 3) appears to be the best solution for the time being.

The middle and upper portions of the Králův Dvůr Formation are characterized by relatively common occurrences of Normalograptus angustus. Although the species characterizes a laterally persistent and restricted stratigraphic interval in the Prague Basin, its known stratigraphic range is extremely long, as shown in many successions in other parts of the world (e.g. Goldman et al. 2011). Dicellograptus laticeps occurs with $N$. angustus through most of its range in the Králův Dvůr Formation. Despite its low abundance, we prefer $D$. laticeps as an index taxon because of the much longer stratigraphic range of $N$. angustus in other areas and we establish the Dicellograptus laticeps Taxon-range Zone (Fig. 3). Its base, although not yet recorded in a continuously sampled section, is defined by the lowest occurrence of D. laticeps. Diplograptus rigidus? occurs in the lower part of the biozone, and Paraplegmatograptus uniformis and Phormograptus chuchlensis occur in the upper part, however all these species are quite rare.

The youngest known specimen of $D$. laticeps has been found several meters below the Perník Bed, slightly below the last occurrence of Normalograptus angustus (specimen CGS SZ 181). Thus, the top of the Dicellograptus laticeps Biozone lies within the upper part of the shaly succession, a few meters below the Perník Bed. The biozone is overlain by approximately 2-5 meters of shale that hosts the last occurrences of $N$. angustus. A subsequent interval of mottled shale, $c$ a $2 \mathrm{~m}$ thick and devoid of graptolites, is topped by the calcareous Perník Bed (Fig. 3).

The shale immediately above the Perník Bed is characterized by locally abundant occurrences of Metabolo- 


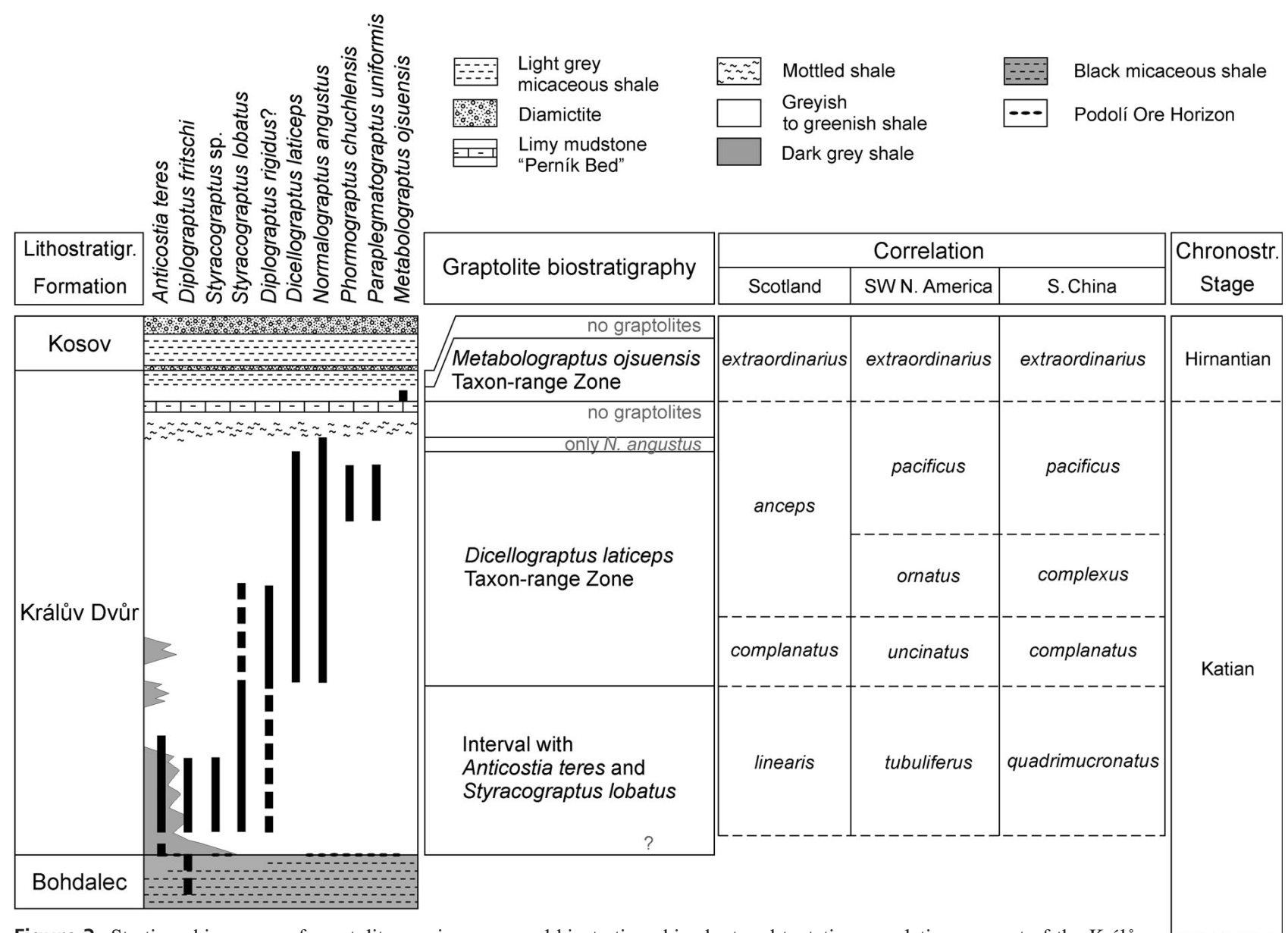

Figure 3. Stratigraphic ranges of graptolite species, proposed biostratigraphic chart and tentative correlation concept of the Králův Dvůr Formation. General lithological and facies features are marked. The correlation is based on stratigraphic charts of Zalasiewicz et al. (2009), Cooper \& Sadler (2012), Chen et al. (2000, 2006).

graptus ojsuensis, which is associated with and succeeded by common specimens of the trilobite Mucronaspis. A formal Metabolograptus ojsuensis Taxon-range Zone can be recognized in this level (Fig. 3). Its base, defined by the lowest occurrence of the index species, coincides with the basal layer of the shale overlying the Perník Bed. Its upper limit, defined by the highest occurrences of M. ojsuensis, lies in shales between the Perník Bed and the basal diamictite of the overlying Kosov Formation. The Metabolograptus ojsuensis Zone is usually only a little more than $10 \mathrm{~cm}$ thick. The shale succession above this zone is barren of graptolites until the lowest occurrences of Metabolograptus persculptus in the uppermost part of the Hirnantian Kosov Formation.

Although the number of graptolite species present in the Králův Dvůr Formation is somewhat higher than that of other units of the Upper Ordovician in the Prague Basin, individual occurrences have relatively low diversity. The maximum number of species coexisting in any portion of the formation (four) is inferred to have occurred in the upper part of the formation (Fig. 3). The diversity in the lower part cannot be reliably evaluated and the maximum illustrated for that interval (Fig. 3) is a composite of ranges recorded from separate localities. We suppose that these species overlapped in time but direct evidence of this is slim and they have never been found together, unlike the small multispecies assemblages of the D. laticeps Zone. The abundance of graptolite specimens in the formation (in distinction from number of species) fluctuates, but overall is higher in the upper beds. However, this rise is purely a product of the relatively common Normalograptus angustus and less common Dicellograptus laticeps in the upper part of the D. laticeps interval, and by the locally abundant monospecific occurrences of Metabolograptus ojsuensis in the uppermost part of the formation.

The paleobiogeographic distribution of the species exhibits a more distinct trend. Three of the four species of the lower part of the formation are so far known only from the Prague Basin. Although Anticostia teres has not previously been reported from outside the study region, this appears to reflect the poor state of knowledge of the species rather than its original range. One of us (CEM, in collaboration 
with Daniel Goldman) has found A. teres commonly in the Pleurograptus linearis Zone of the Dicellograptus Shales at Laeså, Bornholm (Denmark; Goldman collections), and in the Fjåka Shale at Gulleråsen, Dalarne region, Sweden (unnumbered slab, Törnqvist collection, Lund University). Graptolites with a somewhat wider range of palaeogeographic distribution appear in the middle part of the formation, dominate in the upper part and became exclusive in the uppermost portion.

The changes in diversity and biogeographic distribution discussed above may reflect the effects of Late Ordovician climatic fluctuation. The shift toward slightly more common graptolite occurrences with an increasingly cosmopolitan fauna in the $D$. laticeps Zone may represent a local expression of the late Katian temporary warming episode (accompanied by poleward invation of paleotropical species) known as the Boda Event (Fortey \& Cocks 2005; see recent summary in Melchin et al. 2013). That interval contains a peak in the diversity of diplograptine graptolites as it does here in the Prague Basin, and is followed in most parts of the paleotropics by an abrupt replacement of this diverse diplograptine fauna in the earliest Hirnantian by a low diversity assemblage entirely dominated by Neograptina species, and in this case by the monospecific Metabolograptus ojsuensis occurrence in the upper-most Králův Dvưr Formation. We turn below to a discussion of the probable age of these Králův Dvůr Formation occurrences.

Several authors have used graptolites to correlate the Králův Dvůr Formation (e.g., Přibyl 1949, Štorch 1989, and Brenchley \& Štorch 1989). However, it is difficult to correlate the Králodvorian graptolite faunas and biozones even with diverse faunas and zonal schemes of low-latitude palaeogeographic realms. Correlation is possible only with limited precision because of the lack of sufficient diversity of widespread species with relevant correlative potential. Other mid- and high-latitude palaeogeographic realms do not yield reliable correlative graptolite taxa at all.

The lower part of the formation has hitherto yielded solely species with limited paleogeographical extent, as noted above, however, the new records of Anticostia teres in undoubted Pleurograptus linearis Zone strata in the Baltic region (discussed above) dramatically changes this situation. Thus, the strata of the interval with A. teres and Styracograptus lobatus were most likely deposited in mid-Katian time - probably early in the Ashgill or the late Caradoc, early Harju, and late Eastonian series or stage equivalents, or the $\mathrm{Ka} 3$ to $\mathrm{Ka} 2$ time slices of Bergström et al. (2009).

Normalograptus angustus appears to have a very long stratigraphic range (Koren'\& Sobolevskaya in Koren' et al. 1983), but middle Katian records from the paleotropics (e.g. Chen et al. 2005) previously identified as N. angustus are actually referable to Styracograptus (Goldman et al. 2011) and many Rhuddanian occurrences belong to other normalo- graptid species. Reliable records of $N$. angustus range from mid-Katian (Pleurograptus linearis Zone; Skoglund 1963), through the Hirnantian Metabolograptus extraordinarius and Metabolograptus persculptus zones and possibly lowermost Rhuddanian (e.g., Chen et al. 2005, Apollonov et al. 1980).

Dicellograptus anceps, closely related to D. laticeps, is the index species of the uppermost Katian zone in the east-Laurentian southern Scotland (e.g. Williams 1982). Diplograptus rigidus is known from the Paraorthograptus pacificus Zone of Nevada, western Laurentia (Štorch et al. 2011) and from approximately upper Dicellograptus complexus and lower P. pacificus zones of South China (Yangtze Platform, Mu et al. 1993). Paraplegmatograptus uniformis and Phormograptus chuchlensis (which is probably the senior name of Phormograptus connectus) have been found in the D. complexus, $P$. pacificus and M. extraordinarius (former $M$. extraordinarius-M. ojsuensis) zones of South China (Chen et al. 2000), the Dicellograptus ornatus and $P$. pacificus zones in western Laurentia (Štorch et al. 2011), and in the D. anceps Zone of eastern Laurentia (Williams 1982). Thus, on the basis of species ranges, the Bohemian D. laticeps Zone corresponds roughly to $D$. anceps Zone of eastern Laurentia, $D$. ornatus to P. pacificus Zone of western Laurentia and D. complexus to $P$. pacificus Zone of South China.

Rickards (2002) and Zalasiewicz et al. (2009) reported $D$. laticeps (identified as D. praeanceps) from the Pleurograptus linearis Zone of England, i.e. preceding the D. anceps Zone. Although the zonal assignment of the assemblage in which it occurs relied in part on several doubtful specimens of $P l$. linearis, many of the other elements of that fauna are commonly regarded as indicative of the $P l$. linearis Zone. The associated Conochitina rugata Zone and younger chitinozoan faunas (Vandenbroucke et al. 2005), on the other hand, suggest correlation with the $D$. anceps Zone interval in Baltica (Ainsaar et al. 2010), consistent with the inferences above about the age of the D. laticeps-bearing interval in the upper Králův Dvůr Formation.

As mentioned above, the D. laticeps Zone of the Králův Dvůr Formation contains the highest graptolite faunal diversity (per occurrence) and specimen abundance of any interval in the Late Ordovician succession in the Prague Basin and also includes a relatively cosmopolitan fauna. These features, combined with the ranges of the taxa present, suggest that the D. laticeps Zone may actually correspond to some part of the late-phase Boda Event climatic warming in which black shales became widespread in the paleotropics during the $P$. pacificus Zone (Armstrong et al. 2009a, Page et al. 2007, Melchin et al. 2013).

Biostratigraphic correlation of the monospecific assemblage of the zonal index Metabolograptus ojsuensis is also somewhat ambiguous. M. ojsuensis is a secondary marker of the base of the Hirnantian (Chen et al. 2006) and 
its lowest occurrences with respect to those of the primary marker Metabolograptus extraordinarius vary in different areas as discussed by Legrand (2011). It seemed that in the Prague Basin the problem could be solved as Mitchell et al. (2011) reported a specimen of $M$. extraordinarius associated with $M$. ojsuensis from Zadní Třebaň. Our examination of this specimen, however, shows that it is rather broad specimen of M. ojsuensis, furthermore preserved in a specific box-flattened partial relief mode. Thus, $M$. extraordinarius has thus far not been recovered in the periGondwanan Europe. Indirect evidence of an Hirnantian age for the shale interval between the Perník Bed and the first diamictite is provided by the earliest occurrence of the Hirnantia Fauna 5-7 cm below the diamictite at the base of the overlying Kosov Fm. as documented by Mergl (2011a, b) and by the positive excursion in $\delta^{13} \mathrm{C}_{\mathrm{org}}$ through this interval shown by Mitchell et al. (2011; Fig. 2). The steep rising limb of this excursion passes through the Perník Bed and $\delta^{13} \mathrm{C}_{\text {org }}$ values peak immediately below the lowermost Kosov Fm. diamictite. This part of the $\delta^{13} \mathrm{C}_{\text {org }}$ curve at Vinini Creek, Nevada (LaPorte et al. 2009, Štorch et al. 2011) and at several other sites (most notably at Mirny Creek, Siberia; Kaljo et al. 2012) contains the base of the M. extraordinarius Zone. These data suggest that the M. ojsuensis Biozone of the uppermost Králův Dvůr Formation is most likely early Hirnantian in age.

Havlíček \& Vaněk (1966) established several stratigraphical "horizons" based on the apparent stratigraphical succession of some typical benthic faunal associations, especially trilobites, revealed by the detailed field studies by Chlupáč (1951a, b, 1953). This scheme has been modified and gradually transformed into a model of trilobite associations that reflect both the stratigraphical succession and regional facies distribution (e.g. Shaw 2000) and was also combined with a similar model of brachiopod associations (or assemblages or communities) by several authors (e.g. Havlíček \& Vaněk 1966, Havlíček 1982, Havlíček in Chlupáč et al. 1998). Recent revision of trilobite associations by Budil et al. (2011b) suggests that the main part of the stratigraphic range of Amphitrion-Kloucekia Association falls within the Dicellograptus laticeps Biozone because the index species, as well as Dicellograptus anceps, are usually found in shales with benthic elements typical for that association. The Metabolograptus ojsuensis Biozone occupies the lowermost part of the stratigraphic range of the Mucronaspis Association. It corresponds to layers with the richest fossil content of this benthic association, the composition of which is generally considered to be a response to cooling (Štorch \& Mergl 1989).

Special attention has been paid to the so called Lejškov facies (Budil et al. 2011b) occurring in the lower part of the Králův Dvůr Formation because of its abundant and characteristic fossils collected mainly in $19^{\text {th }}$ century. Havlíček \& Vaněk (1966) called this assemblage the "Lejškov" fauna association (biofacies, in current usage). The typical historical material came from dark grey shale (Fig. 3). Budil et al. (2011b), however, did not recognize the Lejškov facies as a formal faunal association. Recent field research at Lejškov suggests that the typical fauna of the dark shale has a wider stratigraphic range reaching higher in the Králův Dvůr Formation than supposed before (Budil et al. 2011a). However, the historical Lejškov material that preserved in the characteristic dark shale lithofacies contains only Anticostia teres and apparently belongs to a limited stratigraphic interval in the lower part of the formation.

\section{The Králodvorian and its delimitation}

Havlíček \& Marek (1973) originally established the Králodvorian Stage as a Series of regional value, corresponding to the Králův Dvůr Formation. Although this unit has been used subsequently in the Mediterranean realm of periGondwana (Gutiérrez-Marco et al. 2002), its loose definition has relied on distinctive lithology and benthic faunas. Thus, the Králodvorian represents an interval characterized by both facies that are different from underlying as well as overlying units and by a specific succession of faunal associations that reflect distinct conditions widespread in the peri-Gondwanan Europe of that time. These are criteria irrelevant to the definition of a formal chronostratigraphic unit because of their heterochronous nature. Any redefinition of Králodvorian as a regional chronostratigraphic unit should be based upon isochronous markers. As is obvious from the above, graptolites are of low value to resolve this task. However, the upper limit of the Králodvorian can be recognized by the first appearance of Metabolograptus ojsuensis immediately followed by typical elements of benthic Hirnantian fauna (Fig. 3).

\section{Systematic part}

Despite approximately 150 years of research and fossil collecting in the Králův Dvůr Formation, the graptolite material is quite limited and housed in only a few collections: National Museum in Prague (specimens with prefix NM), Faculty of Science, Charles University in Prague (FSCU), Czech Geological Survey in Prague (CGS), West Bohemian Museum in Pilsen (WBM), and the J. Schary Collection reposited in the Agassiz Museum of Comparative Zoology, Harvard University (MCZ). The present revision further benefits from the authors' own collections, discovery of "forgotten" material in historical collections at the Faculty of Science, and overlooked material in the Schary Collection. For descriptions in the following chapter we use biometric features as characterized by Štorch et al. (2011; fig. 7 for Dicellograptus and fig. 13 for biserials). 
Occurrences are listed under short locality names if possible. Full names are given in the explanation to Fig. 1.

Order Graptoloidea Lapworth in Hopkinson \& Lapworth, 1875, emend. Fortey \& Cooper, 1986

Suborder Axonophora Frech, 1897, emend. Maletz et al., 2009

Infraorder Diplograptina Lapworth, 1880, emend. Štorch et al., 2011

Superfamily Dicranograptoidea Lapworth, 1873; emend. Mitchell et al., 2007

Family Dicranograptidae Lapworth, 1873

\section{Genus Dicellograptus Hopkinson, 1871}

Type species. - Didymograptus elegans Carruthers, 1867, p. 369, pl. 2, fig. 16a; subsequently designated by Gurley 1896, p. 70.

\section{Dicellograptus laticeps Štorch, 1989}

Figures 4B-F; 11A-B, F-G

1895 Dicellograptus anceps Nicholson. - Perner, p. 43, pl. 7, fig. 17; pl. 8, figs 2-4; text-figs 3-6; non pl. 8, fig. 1 (distorted Normalograptus angustus).

1989 Dicellograptus cf. anceps (Nicholson). - Štorch \& Mergl, pl. 4, fig. 5.

1989 Dicellograptus laticeps sp. n.; Štorch, pp. 175-177, pl. 1, figs 1, 2, 6, 8; text-fig. 1A-C, E-G.

1989 Dicellograptus cf. morrisi Hopkinson. - Štorch, pp. 175-177, pl. 1, figs 4, 5; text-fig. 1D, H.

2002 Dicellograptus praeanceps sp. nov.; Rickards, pp. 6-7, text-fig. 5.

Holotype. - Specimen NM L27514 from Králův Dvůr designated and figured by Štorch (1989) on pl. 1, fig. 8 and text-fig. 1B; previously also figured by Perner (1895) on text-fig. 5 .

Material. - 21 specimens (NM L27511, L27514, L27523, L27533, L27761, L27762, L40983; FSCU 909, 5169, 5173 - counterpart to NM L27533, 5174, 5175, 1 specimen without number - counterpart to part of CGS BB653/1; CGS BB653/1 - 2 specimens, CGS PŠ311, PŠ312, PŠ314; WBM S 05148; MCZ 196546, 196547, 2 specimens without numbers) with proximal part and several stipe fragments. The specimens include individuals preserved in moderate relief as well as flattened. Generally specimens have been recovered as single individual colonies. Only at the Králův Dvůr historical locality have multiple specimens (often complete) been found together, where they comprise largely monospecific accumulations of speci- mens of different size. Occasionally rhabdosomes were accompanied by specimens of Normalograptus angustus.

Description. - Sicula 0.16-0.24 mm wide, apical part resorbed during colony growth; all adult rhabdosomes display only sicular residua $0.55-0.8 \mathrm{~mm}$ long. Nearly complete sicula recorded in one juvenile specimen (Fig. 4C; possessing 3 thecae in stipe) is $1.2 \mathrm{~mm}$ long. Nema not observed. Virgella 0.35 to 0.45 (max. 0.5 ) mm long. Stipes usually more than $20 \mathrm{~mm}$ long; longest recorded: $67.5 \mathrm{~mm}$ (Fig. 11F). The stipes initiate with narrow, 1.25-1.4 mm wide axil in which th $1^{1}$ and th $1^{2}$ grew sub-horizontally to slightly reclined, then, behind mesial spines, turned sharply upward (dorsally) forming relatively narrow, rounded axil. Initial angle of divergence (first one to two centimeters) ranges between $20^{\circ}$ and $40^{\circ}$. Three unusual specimens exhibit stipe divergence of $65^{\circ}$ to as much as $83^{\circ}$. Thus, proximal shape highly variable, ranging from narrow to less frequently open. Proximal stipe segments of variable length, usually straight to almost straight, becoming slightly dorsally flexed distally, or less commonly slightly dorsally flexed throughout. Long stipes form narrow and high double helix accompanied by rotation of the stipes. Depending on growth stages of stipes and their distortion on bedding planes, angle of divergence and orientation of thecae change in the distal portion (e.g., Figs 4B, 11F) as thecal apertures continually faced outward from the helix. Thickened proximal part of stipes combined with resorbed sicula form a narrow U-shaped dorsal arch. Exceptionally, a small membrane fills the axil of mature rhabdosomes (Fig. 4E with tiny, probably initial membrane, 4F with advanced, sickle-like membrane) to an observed maximum height of $0.45 \mathrm{~mm}$ in the sicular axis. Stipes $0.45-0.5 \mathrm{~mm}$ wide at th $1^{1}$ and $1^{2}, 0.45-0.5 \mathrm{~mm}$ at th $2^{1}, 0.45-0.55 \mathrm{~mm}$ at th $2^{2}$ and gradually broaden to $0.5-0.65 \mathrm{~mm}$ at th 3 and th 4 , $0.6-0.7 \mathrm{~mm}$ at th5, 0.6-0.75 $\mathrm{mm}$ at th6, 0.75-0.8 $\mathrm{mm}$ at th7, 0.75-0.85 $\mathrm{mm}$ at th8 an th9, 0.8-0.95 $\mathrm{mm}$ at th 10 , reaching maximum of $0.9-0.95 \mathrm{~mm}$ usually at the level of th9 to th12; maximum observed stipe width is $1.1 \mathrm{~mm}$ in a long stipe fragment. Stipe expansion curve (for method see Cooper \& Fortey 1982) has almost linear trend and a low slope. Thecae dicellograptid with angular genicula; apertures introverted and weakly to strongly introtorted. Thecae $1^{1}$ and $1^{2}$ are $0.5-0.65 \mathrm{~mm}$ long; distal thecae reach $1.6-1.8 \mathrm{~mm}$ in length and overlap for less than one half their length. Interthecal septa inclined at $18-25^{\circ}$, and supragenicular ventral walls parallel to slighly inclined to stipe axis. Basal spines developed in th $1^{1}$ and $1^{2}$ are 0.2 to $0.3 \mathrm{~mm}$ long (max. 0.35) and 0.04-0.09 mm wide at their base. Much shorter mesial spines occur on convex supragenicular ventral thecal walls up to th6 to th11. Specimen NM L40983 exhibits a genicular rim resembling a short spine but this is a preservational artifact. Thecal spacing (2TRD) increases from $1.25-1.5 \mathrm{~mm}$ at th2, through $1.75-1.9 \mathrm{~mm}$ 

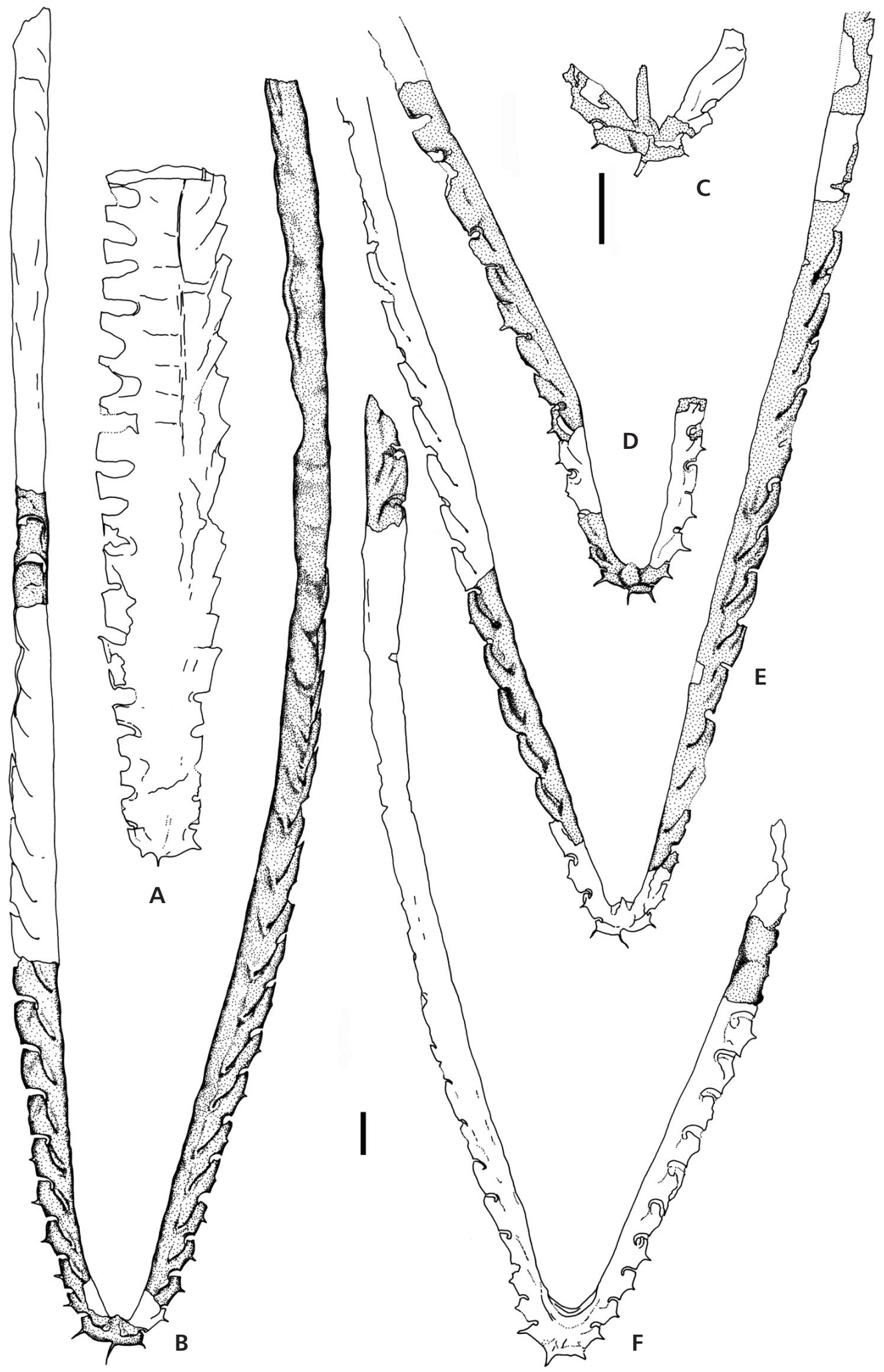

Figure 4. A - Diplograptus rigidus (Lee in Wang, 1974)?: FSCU 5165 (external mold). B-F - Dicellograptus laticeps Štorch, 1989: B - NM L27514 (holotype, relief specimen); C - WBM S 05148 (flattened juvenile specimen with preserved sicula); D - FSCU 5169 (relief specimen, partly exfoliated); E-FSCU 5175 (specimen in partial relief with initial membrane); F-FSCU 5173 (low relief external mold, specimen with advanced membrane), figured by Perner (1895, pl. 8, fig. 3) and counterpart of the specimen, NM L27533, figured by Perner (1895, pl. 7, fig. 17) and refigured by Štorch (1989, fig. 1A). All specimens from Králův Dvůr, except C from Praha-Radotín - highway tunnel. All figures $\times 6$, except $\mathrm{C} \times 10$. Scale bars equal $1 \mathrm{~mm}$. 
Table 1. Dicellograptus laticeps Štorch, 1989. Dimensions of illustrated, type and other selected specimens (in mm); L-length, W - width. References on previously figured specimens only in cases not mentioned in the text or explanations of figures.

\begin{tabular}{|c|c|c|c|c|c|c|c|c|c|c|c|}
\hline \multirow{2}{*}{ Specimen No. } & \multirow{2}{*}{ Figures } & \multirow{2}{*}{ Sicula L } & \multirow{2}{*}{ Axil W } & \multirow{2}{*}{$\begin{array}{l}\text { Number of spinose } \\
\text { thecae }\end{array}$} & \multicolumn{4}{|c|}{ Stipe W } & \multicolumn{3}{|c|}{ 2TRD } \\
\hline & & & & & th1 & th3 & th10 & dist. & th2 & th5 & th10 \\
\hline NM L27514 & \multicolumn{2}{|l|}{ 4B (holotype) } & 1.4 & $\sim 10$ & 0.6 & 0.65 & 0.95 & 0.95 & 1.45 & 1.8 & 2.05 \\
\hline NM L40983 & - & 0.8 (partly absorbed) & 1.45 & 8 & 0.55 & 0.6 & 0.85 & 0.9 & 1.5 & 1.9 & 1.95 \\
\hline WBM S 05148 & $4 \mathrm{C}$ & 1.2 & 1.3 & $?$ & 0.5 & - & - & - & - & - & - \\
\hline FSCU 5169 & $4 \mathrm{D}, 11 \mathrm{~B}$ & absorbed & 1.25 & $\sim 9$ & 0.55 & 0.6 & 0.75 & 0.9 & 1.45 & 1.65 & 1.95 \\
\hline FSCU 5175 & $4 \mathrm{E}$ & absorbed & 1.25 & $\sim 9$ & 0.5 & 0.55 & 0.8 & 0.85 & 1.4 & 2.0 & 2.05 \\
\hline FSCU 5173 & $4 \mathrm{~F}$ & membrane & 1.45 & $\sim 11$ & 0.6 & 0.55 & 0.8 & 0.95 & 1.35 & 1.7 & 1.95 \\
\hline MCZ 196546 & $11 \mathrm{~A}$ & absorbed & $\sim 0.9$ & ? (only 2 visible) & 0.45 & 0.55 & 0.9 & 0.9 & 1.25 & - & 1.95 \\
\hline MCZ 196547 & $11 \mathrm{~F}, \mathrm{G}$ & 0.6 (partly absorbed) & 1.3 & $?(\sim 7-8)$ & 0.4 & 0.55 & 0.8 & 0.85 & 1.3 & 1.8 & 2.05 \\
\hline \multicolumn{2}{|c|}{$\begin{array}{r}\text { CGS BB 653/1 ( } \text { Šrtorch 1989, } \\
\text { text-fig. 1D) }\end{array}$} & 0.5 (part missing) & 1.25 & clearly visible in 3 & 0.45 & 0.5 & - & - & 1.35 & 1.8 & - \\
\hline \multicolumn{2}{|c|}{$\begin{array}{r}\text { CGS BB 653/2 (Štorch } 1989, \\
\text { text-fig. } 1 \mathrm{H})\end{array}$} & $\begin{array}{l}0.6 \text { (partly absorbed and } \\
\text { surrounded by minute membrane) }\end{array}$ & 1.2 & only in $1^{\text {st }}$ pair visible & 0.45 & 0.5 & - & 0.85 & 1.1 & - & - \\
\hline
\end{tabular}

at th5 and 1.95-2.05 $\mathrm{mm}$ at the 10 to 2TRD of $2.0-2.2 \mathrm{~mm}$ distally. Measured thecal density $12-13$ in $10 \mathrm{~mm}$ proximally and 9-9.5 distally.

Remarks. - This species characteristically has a narrow, U-shaped axil, small basal spines on first thecal pair followed by a number of spiny thecae. Thecae are relatively closely spaced compared to stipe width and strongly geniculate. The general shape of the rhabdosome on bedding planes varies depending on the orientation of the different growth stages of double helical rhabdosome prior to flattening. The stipes may be straight or flexed in different ways as a whole or in part as a result of that distortion. The angle of divergence also ranges over a very wide interval. Williams (1981) has shown that primary variability in stipe angle is enhanced by the preservational effects of stipe flattening in different orientations. The orientation of stipes and thecae also influence the preservation of mesial spines, ranging from fully preserved series to no spines preserved. In addition, preservation of spines can differ between stipes on a single specimen. Thus, divergence and course of stipes and mesial spines, combined with original variability have to be assessed based on a sufficient number of specimens to show the range of both primary and preservational variations. Their misinterpretation, in general, can bias the identification and classification of dicellograptids.

Only a few dicellograptid species exhibit spinose proximal thecae beyond the first pair. Among them are D. gurleyi Lapworth in Gurley, 1896 and D. flexuosus Lapworth, 1876, which are considerably older and markedly different in form. A conspicuous sicula is preserved in adult colonies in both taxa and the former is much more slender. Some similarities in biometric features can be traced in the latter species but their thecae are more widely spaced and the stipes are more strongly divergent, forming an open arched proximal end. Only two coeval species, D. anceps Nicholson, 1867 and D. morrisi Hopkinson,
1871 have numerous spinose thecae beyond the first pair. The more open, almost symmetrical proximal end together with narrower stipes, slightly longer distal thecae and denser thecae proximally represent significant differences from the very similar $D$. anceps. The biometric parameters of $D$. morrisi are even closer to those of $D$. laticeps but the key difference is in the position of its mesial spines as suggested by Rickards (2002). D. laticeps (as well as D. anceps) has spines situated usually slightly above the half length of supragenicular wall while D. morrisi possesses supramesial spines positioned subaperturally. The latter species also has more open axil and much wider angle of stipe divergence in most specimens. Štorch (1989) assigned two specimens (Fig. 1D, H therein) to $D$. cf. morrisi. The shape of the rhabdosome in these specimens does resemble that of $D$. morrisi, but the preserved mesial spines are not as high on the supragenicular wall as in that species. It should be noted that the spines on the left stipe of the specimen figured by Štorch (1989, fig. 1D) appear to occupy slightly higher positions than typical of $D$. laticeps but we regard this as a preservational artifact and consider the specimen to be within the variability of that species.

Rickards (2002) described D. praeanceps as a descendent of $D$. morrisi and an ancestor of $D$. anceps. The overall shape and biometric data of the type specimens of $D$. praeanceps fit with those of $D$. laticeps. We consider $D$. praeanceps to be conspecific with $D$. laticeps and the deduced lineage to be questionable due to the doubtful correlation of the biostratigraphic ranges (Rickards 2002).

Occurrence. - Králův Dvůr, Levín, Liteň, Praha-Malá Ohrada, Praha-Radotín - highway tunnel, Praha-Velká Chuchle; middle and upper part of Králův Dvůr Formation. In addition to Bohemia, the species is known from England.

A stipe fragment in dark grey shale reposited in the National Museum (without inventory number) from Lejškov was identified as undeterminable Dicellograptus. It is 
poorly preserved but several thecae in oblique orientation at one end manifest typical dicellograptid thecal excavations. Its stratigraphic position is unknown but it supports the concept of Budil et al. (2011a), discussed above, on the apparently wider stratigraphic range of the locality than supposed before.

Superfamily Diplograptoidea Lapworth, 1880; emend. Mitchell et al., 2007

Family Diplograptidae Lapworth, 1873; emend. Mitchell et al., 2007

\section{Genus Diplograptus McCoy, 1850, emend. Mitchell et al., 2009}

Type species. - Prionotis pristis Hisinger, 1837, p. 114, pl 35, fig. 5; subsequently designated by Gurley 1896, p. 78 .

\section{Diplograptus rigidus (Lee in Wang, 1974)?} Figure 4A

1974 Orthograptus rigidus; Lee in Wang, p. 746, pl. 29, figs 10, 11.

1988 Orthograptus rigidus Lee. - Li \& Cheng, pp. 168-169, pl. 1, fig. 7; text-fig. 2a, b.

1993 Orthograptus rigidus Lee. - Mu et al., pp. 191-192, pl. 42, figs $1-3$.

1993 Orthograptus augescens sp. nov.; Li in $\mathrm{Mu}$ et al., pp. 193-194, 347, pl. 43, figs 5, 6, 9, 14, 15.

1993 Orthograptus yangtziensis sp. nov.; Li in $\mathrm{Mu}$ et al., pp. 194, 347-348, pl. 43, figs 8, 10, 11, 16.

2009 Diplograptus rigidus (Lee). - Mitchell et al., fig. 21.

2011 Diplograptus rigidus (Lee in Wang). - Štorch et al., pp. 328-329, fig. $15 \mathrm{I}$.

Holotype. - Not traced.

Material. - Three poorly preserved specimens, one box-flattened, preserved as a distorted, semi-relief external mold with proximal end (FSCU 5165), the other two as partly exfoliated flattened molds without proximal end on a single slab (NM L28041). All situated on bedding planes coated with limonite. It could be that some crumpled rhabdosomes compressed in axial direction, i.e. with significant distortion component reducing the length of the colony (NM without number) belong to the same taxon.

Description. - The studied specimens attain length of $16.5 \mathrm{~mm}$. Rhabdosome relatively robust, widens rapidly from $1.6 \mathrm{~mm}$ at the first thecal pair, through $1.85 \mathrm{~mm}$ at th2, $2.0 \mathrm{~mm}$ at th3, $2.1 \mathrm{~mm}$ at th4 and $2.3 \mathrm{~mm}$ at th5 to maximum $3.3 \mathrm{~mm}$ at th 15 . Mode of flattening accounts for rather rectangular cross section with subrounded ventral thecal profile in figured specimen. Sicula not observed but short virgella present. Proximal end wide, blunt and weakly asymmetric. Th $1^{1}$ and th $1^{2}$ turn outwards and only slightly upwards from sicula initially but turn sharply upwards at the level of short, robust mesial spines developed on both thecae. The subsequent thecae are sharply geniculate proximally with short supragenicular wall becoming weakly geniculate distally. Apertural excavations $0.5-0.6 \mathrm{~mm}$ high throughout; supragenicular walls become shorter in distal thecae (Fig. 4A) where height of the apertural excavation equals the length of the supragenicular wall. Two-thecae repeat distance (2TRD) in measurable portions of the limited material: $1.45 \mathrm{~mm}$ at th2; $1.7 \mathrm{~mm}$ at th5. Thecae number 13 in $10 \mathrm{~mm}$ proximally and 10 in $10 \mathrm{~mm}$ distally. Rhabdosome seems to be partially aseptate. Specimens compressed axially, and assigned to this taxon only with reserve (NM without number; see material), display distortion that suggests median septum not present. In the best-preserved, almost complete box-flattened specimen (Fig. 4A), however, a trace of a low ridge in the external mold indicates the presence of septum beginning at th11.

Remarks. - Despite poor preservation three fragments match well with emended characteristics of Diplograptus, including thecal style, short virgella and distal shortening of the supragenicular wall (Mitchell et al. 2009). Although many species of Diplograptus are septate, the appearance of the median septum is generally delayed, often considerably. The present aseptate specimens may have such a delayed development of the septum. The architecture of the very broad proximal end and the closely spaced thecae, discussed by Štorch et al. (2011), are typical of D. rigidus and all measurable biometric parameters agree with this species. Thus, we assign the three specimens to this taxon with reservation simply because of the unfavorable preservation of the limited material available for study. The assignment of other distorted rhabdosomes is more doubtful. The thecae of these distorted rhabdosomes more closely resemble those of Anticostia.

Occurrence. - Králův Dvůr; middle part of the Králův Dvůr Fm., questionably also from its lower part. D. rigidus also occurs in South China and western Laurentia (Nevada), making this the first extra-tropical record of the species if confirmed by better material.

\section{Diplograptus fritschi Perner, 1895}

Figures 7K, 10A-E, 12A, 13A, E

1895 Diplograptus rugosus Emmons var. Fritschi mihi; Perner, p. 29, pl. 8, fig. 7. 


\begin{tabular}{lllllll|lll}
\hline Specimen No. & Figures & \multicolumn{4}{c}{ W } & \multicolumn{4}{c}{ 2TRD } \\
\cline { 3 - 9 } & & th1 & th5 & th10 & dist. max & th2 & th5 & th10 & dist. th \\
\hline NM L27520 & 10C (holotype) & $?$ & 1.75 & $\sim 2.1$ & - & - & $\sim 2.0$ & - & - \\
NM L27520 & 10A & - & - & - & 2.25 & - & - & - & 2.25 \\
NM L27520 & 10B & - & - & - & $\sim 1.7$ & - & - & - & 2.25 \\
WBM S 05151 & 10E, 11E & $\sim 1.05$ & 1.8 & - & 2.05 & $\sim 1.7$ & 2.1 & - & 2.65 \\
WBM S 05152 & 10D, 11A & 1.35 & 2.0 & - & - & 1.65 & 1.65 & - & - \\
WBM S 05155 & $7 \mathrm{~K}, 12 \mathrm{~A}$ & 1.15 & 1.75 & 2.35 & 3.25 & 1.55 & I.75 & 2.15 & 2.7 \\
\hline
\end{tabular}

Table 2. Diplograptus fritschi Perner, 1895. Dimensions of illustrated specimens (in $\mathrm{mm}$ ); $\mathrm{W}$ - width. References of previously figured specimens mentioned in the text and explanation of figures.
1949 Rectograptus truncatus fritschi (Perner). - Přibyl, pp. 26-27, pl. 3, figs $7,8$.

Holotype. - Specimen NM L27520 from Králův Dvůr (Königshof) figured by Perner (1895) pl. 8, fig. 7, refigured by Přibyl (1949) pl. 3, fig. 7 and herein Fig 10C; designated by Přibyl (1949) by monotypy.

Material. - Two solitary specimens (WBM S 05151, WBM S 05152) and two clusters of several specimens with a few moderately well-preserved rhabdosomes (NM L27520, WBM S 05155), however most material is partially obliquely compressed longitudinally or laterally boxflattened.

Description. - Partly septate, robust rhabdosome usually ca $30 \mathrm{~mm}$ long, but up to $48.5 \mathrm{~mm}$. Rhabdosome widens gradually from $1.15-1.35 \mathrm{~mm}$ at first thecal pair, $1.3-1.7$ at th2, 1.3-2.0 mm at th3, 1.75-2.2 $\mathrm{mm}$ at th5 to $2.35-2.5 \mathrm{~mm}$ at th10. Width $2.6 \mathrm{~mm}$ at 18th thecal pair and $3.25 \mathrm{~mm}$ at the end of the largest specimen. Proximal end rather asymmetrical and V-shaped, with first pair weakly curved and moderately to strongly inclined outward. Sicula 0.25-0.3 mm wide across a straight aperture from which virgella, up to $0.95 \mathrm{~mm}$ long, projects. Sicula exposed on obverse side until enclosed by th $2^{2}$ protheca. Thin nema ( $0.03 \mathrm{~mm}$ wide) free in the aseptate portion. Downwardgrown portion of th $1^{1}$ about $0.6 \mathrm{~mm}$ long, descends along the sicula and turns upward slightly below the level of the sicular aperture. After hook-like bend, upward-grown portion extends upward and outward for another $0.65-0.9 \mathrm{~mm}$. Th1 ${ }^{2}$ emerges from dorsal outline of sicula $0.25-0.3 \mathrm{~mm}$ above the sicular aperture and extends upwards and outwards. Length of th $1^{2}$ is $0.5-0.9 \mathrm{~mm}$. Subsequent thecae of the aseptate portion of the rhabdosome possess a convex infragenicular ventral wall with rounded geniculum and convex supragenicular wall; supragenicular walls become rapidly shorter over the first 6-8 thecae as infragenicular walls develop long triangular concavity (i.e., acquire a pseudogenicular structure; Figs 7K, 10E). The median septum appears from the level of th $9^{1}-10^{1}$. Thecae in the septate part become nearly straight with slight ventral convexity, distinct in prothecal part and fading towards the aperture. Thecal length increases from $1.3-1.8 \mathrm{~mm}$ at th3 through $1.65-2.0 \mathrm{~mm}$ at th5 to $2.5 \mathrm{~mm}$ at th10. Interthecal septa are developed as thecae overlap for half their length or slightly more in the distal, septate part of the rhabdosome. Thecae incline at an angle of about $20^{\circ}$ to the rhabdosome axis (measured values vary between $16^{\circ}$ and $26^{\circ}$ ). Thecal density decreases from $9.5-12$ in $10 \mathrm{~mm}$ proximally to 8-9 in $10 \mathrm{~mm}$ distally. Accordingly, the 2TRD increases from $1.5-1.7 \mathrm{~mm}$ at th2, through $1.65-2.15 \mathrm{~mm}$ at th5 and $2.0-2.25 \mathrm{~mm}$ at th10 to distal maximum $2.65-2.7 \mathrm{~mm}$. Thecal apertures are $0.35-0.6 \mathrm{~mm}$ wide, approximately perpendicular to thecal axis to weakly everted. Thecae alternate regularly in aseptate portion of the rhabdosome, become subalternating to almost opposite in the distal, septate portion.

Remarks. - This species is the largest biserial graptolite recorded in the Králův Dvůr Formation. The large, continuously widening rhabdosome with its steadily lengthening thecae, the character of these biform thecae, proximal shape and aseptate proximal portion all fit the combination of characters of Diplograptus (Mitchell et al. 2009). The proximal structure of the available material appears to be quite simple and resembles Pattern $\mathrm{G}$ or $\mathrm{H}$ rather than other more complex patterns, which also is consistent with assignment to Diplograptus. The lack of subapertural spines on the first pair of thecae is atypical for species of that genus, however. On the other hand, the preservation of the available specimens is generally unfavorable (the best is that shown in Fig. 7K), and so the full character of the thecae and development of proximal spines is somewhat uncertain. The thecal spines in the type species D. pristis (Hisinger, 1837) are relatively small and similar spines might be missed in the present material or they may indeed be absent. Apart from the proximal thecal spines, the present species differs from Diplograptus rarithecatus (Ross \& Berry, 1963), which is the most widespread species of the genus, in that rhabdosomes of $D$. fritschi widen more rapidly and possess slightly longer thecae. Again excepting the proximal spine configuration $D$. fritschi is most similar to material reported from South China $(\mathrm{Mu}$ et al. 1993), and particularly to Diplograptus palaris Lin in Mu et al., 1993, which matches the present form in all its 
dimensions as well as in the general rhabdosome shape and structure. D. palaris, however, is based on mildly structurally deformed material and, like $D$. fritschi, relatively few specimens, so the precise relationship of these taxa is unclear.

Occurrence. - Králův Dvůr (one slab with type specimen), Praha-Vršovice (Eden, construction site), Praha (probably Vršovice); uppermost Bohdalec Formation (?) and lower Králův Dvůr Formation. The species is known only from Bohemia. Futhermore, this species has not been found in association with any other graptolite taxon and its precise location within the stratigraphic succession is uncertain. Based on the accompanying fauna it seems to occur in a relatively deep-water biofacies. Several features of the D. fritschi occurrences help to locate them within the Králův Dvưr succession: the facies character of the shale in which it occurs is slightly darker than then is usual in the middle and upper parts of the formation, the absence of Normalograptus angustus or Dicellograptus laticeps (which might be expected in the upper part of the Králův Dvůr Formation), the stratigraphic context of the localities from which the material was collected and, finally, the accompanying poor and low diversified shelly fauna. These features suggest that $D$. fritschi may have been a contemporary of Anticostia teres and Styracograptus lobatus within the lower part of the Králùv Dvưr Formation.

\section{Genus Anticostia Stewart \& Mitchell, 1997, emend. Štorch et al., 2011}

Type species. - Anticostia macgregorae Stewart \& Mitchell, 1997, pp. 221-225, figs 5A-M, pl. 1; by original designation.

\section{Anticostia teres (Perner, 1895)}

Figures $5 \mathrm{~A}-\mathrm{G}, 11 \mathrm{E}$

1870 Diplograptus teres Barrande; p. 126; nomen nudum. 1895 Diplograptus (Glyptograptus) teres Barrande (in litt.). - Perner, p. 28, pl. 8, figs 13a, b.

1949 Glyptograptus teres (Perner). - Přibyl, pp. 11-12, pl. 2, figs 12,13 .

Holotype. - Specimen NM L27529 from Lejškov figured by Perner (1895) pl. 8, figs 13a, b, refigured by Přibyl (1949) pl. 2, fig. 12 and herein Fig. 5E; designated by Přibyl (1949) by monotypy.

Material. - 12 fragmentary rhabdosomes (NM L27529, L28043, L40986 - 2 specimens, L40987 and 4 specimens without number; FSCU 5158, PK 25 and 1 specimen without number) from Lejškov and possibly one incomplete re-

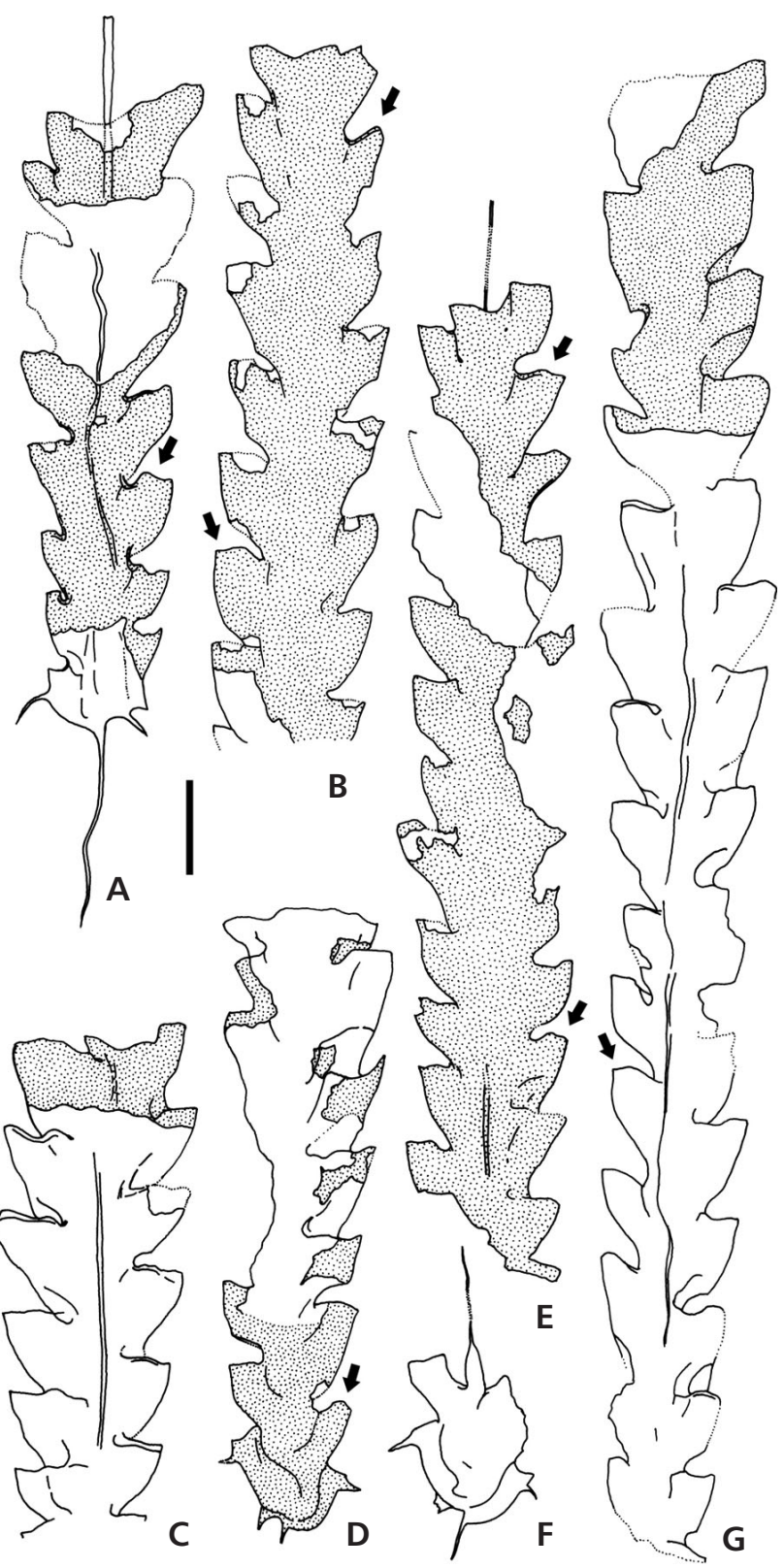

Figure 5. Anticostia teres (Perner, 1895): A - FSCU PK 25; B - NM L28043, specimen figured by Přibyl (1949, pl. 2, fig. 13); C - NM L40987; D - FSCU 5158; E - NM L27529 (holotype); F - NM L40986a; G - NM L40986b. All specimens flattened, periderm partly exfoliated. All specimens from Lejškov. Arrows point to apertural lappets. All figures $\times 10$, scale bar equals $1 \mathrm{~mm}$.

lief specimen from Podolí Ore Horizon at the base of the Králův Dvůr Formation (NM without number). All specimens from Lejškov are solitary, flattened in dark grey shale. Colonies preserved as uniform, black carbonaceous film displaying only few details; often exfoliated.

Description. - All available specimens are relatively small colonies up to $16.5 \mathrm{~mm}$ long. Aseptate rhabdosome with glyptograptid thecae that bear prominent apertural cusps; 


\begin{tabular}{|c|c|c|c|c|c|c|c|c|c|c|}
\hline \multirow{2}{*}{\multicolumn{2}{|c|}{ Specimen No. Figures }} & \multicolumn{5}{|c|}{$\mathrm{W}$} & \multicolumn{4}{|c|}{ 2TRD } \\
\hline & & th1 & th3 & th5 & th10 & dist. max. & th2 & th5 & th10 & dist. th \\
\hline NM L27529 & 5E (holotype) & - & - & - & - & 2.05 & - & - & - & 2.1 \\
\hline NM L28043 & $5 B$ & - & - & - & - & 1.8 & - & - & - & 2.1 \\
\hline NM L40986a & $5 \mathrm{~F}$ & 1.35 & - & - & - & - & - & - & - & - \\
\hline NM L40986b & $5 \mathrm{G}$ & - & - & $\sim 1.75$ & $?$ & 2.2 & - & $\sim 1.9$ & $\sim 1.9$ & 2.2 \\
\hline NM L40987 & $5 \mathrm{C}$ & - & - & - & - & 2.1 & - & - & - & 1.95 \\
\hline FSCU 5158 & $5 \mathrm{D}, 11 \mathrm{E}$ & 1.2 & 1.5 & 1.75 (th7) & - & - & 1.8 & 1.8 & - & - \\
\hline FSCU PK 25 & $5 \mathrm{~A}$ & 1.25 & 1.4 & 1.8 (th7) & - & - & 1.4 & $\sim 2.0$ & - & - \\
\hline
\end{tabular}

Table 3. Anticostia teres (Perner, 1895). Dimensions of type and illustrated specimens (in $\mathrm{mm})$; W - width. References of previously figured specimens mentioned in the text and explanation of figures. widens gradually from $1.2-1.35 \mathrm{~mm}$ at first thecal pair, through 1.4-1.5 $\mathrm{mm}$ at th3 and 1.75-1.8 $\mathrm{mm}$ at th5, and attaining a uniform maximum $2.05-2.3 \mathrm{~mm}$ at $\sim 8-10^{\text {th }}$ pair. Proximal end strongly asymmetrical, broadly rounded. Sicula $0.2 \mathrm{~mm}$ wide at aperture; virgella slender, varies from a short spine to one as much as $2.5 \mathrm{~mm}$ long. Antivirgellar spine (or spines) present but commonly inconspicuous. Prominent, 0.07-0.095 mm wide nema internally free, almost straight to (more commonly) irregularly flexed. Th $1^{1}$ extends $c a 0.2 \mathrm{~mm}$ below the sicular aperture along base of virgella before turning sharply upward in a narrow arc; ascending portion $0.55-0.75 \mathrm{~mm}$ long and bearing a mesial to subapertural spine of 0.15 and $0.4 \mathrm{~mm}$ in length. Gradually arching th $1^{2}$ crosses the sicula slightly obliquely at the aperture or slightly above. Free ventral length of th $1^{2}$ $0.65-0.75 \mathrm{~mm}$, furnished with short subapertural spine ( $0.15 \mathrm{~mm}$ in one in case). Apertures of the first thecal pair $0.3-0.35 \mathrm{~mm}$ wide. Next thecae glyptograptid with 0.45-0.65 mm wide, weakly introverted apertural margin and cuspate apertural lappets (often not well preserved in present material but see arrowed lappets in Fig. 5). Thecal length increases from some $1.4 \mathrm{~mm}$ at th3, through $1.5 \mathrm{~mm}$ at th5 to $1.75-1.9 \mathrm{~mm}$ at th6 and th7. Interthecal septa short, corresponding to $1 / 3$ overlap. Supragenicular walls moderately convex, $0.95-1.05 \mathrm{~mm}$ long, inclined but becoming almost parallel sided near the aperture. Thecae alternating: apertures of thecal series above th $1^{2}$ opposite genicula of th $1^{1}$ series thecae. Thecal spacing increases slightly from $10.5-11.5$ in $10 \mathrm{~mm}$ proximally to $8.5-10$ thecae distally. 2TRD increases from $1.4-1.8 \mathrm{~mm}$ at th2, through 1.8 to $2.0 \mathrm{~mm}$ at th5 and $1.9 \mathrm{~mm}$ at th10, to $1.9-2.2 \mathrm{~mm}$ (exceptionally $2.5 \mathrm{~mm}$ ) distally.

Remarks. - The species is characterized by its wide proximal end and gradual but prominent widening of the rhabdosome. It is also unusual in the presence of a spine on th $1^{2}$. The proximal development of $A$. teres is uncertain, however it is worth noting that the interthecal septum between th $1^{2}$ and th $2^{1}$ (visible in reverse view, Fig. 5D, F) is relatively long and appears to extend across the sicular axis very close to th $1^{1}$. This condition is more like that seen in species with a Pattern $\mathrm{G}$ proximal structure than the Pattern $\mathrm{K}$ structure of most Anitcostia species. Stewart \& Mitchell
(1997) interpreted the proximal structure of Anitcostia? lorrainensis (Ruedemann, 1925) as likely to be Pattern G as well. That species also shares with $A$. teres the occasional presence of a subapertural spine on th $1^{2}$ and a relatively broadly rounded proximal end (Stewart \& Mitchell 1997, fig. 8). Rhabdosomes of $A$. teres are relatively robust compared to those of most other Anticostia species, including those of A.? lorrainensis, which is markedly narrower and has significantly more closely spaced thecae.

Anticostia fastigata (Davies, 1929), Anticostia lata (Elles \& Wood, 1906) and the type species, A. macgregorae Stewart \& Mitchell, 1997, all possess much narrower rhabdosome in the proximal part and generally lower $2 \mathrm{TRD}$, especially $2 \mathrm{TRD}_{2}$. The rate of rhabdosome widening differentiates $A$. teres from the almost parallel-sided rhabdosomes of Anticostia uniformis (Mu \& Lin in Mu et al., 1993), which are also more slender. Perhaps the most similar species is Anticostia hudsoni (Jackson, 1971), 3D material of which is nearly as broad as the present material but has more strongly inclined thecae that are also slightly more closely spaced. The first two thecae in A. hudsoni colonies are less strongly upwardly directed than in A. teres, which results in a slightly more bluntly rounded proximal end. Finally, A. hudsoni rhabdosomes lack a spine on th $1^{2}$.

Based on the distortion style of several aseptate rhabdosome fragments from Králův Dvůr deposited in NM and FSCU (axially compressed specimens in greyish-green shale) it is possible that these specimens (all without numbers) may also belong to A. teres.

One fragment of an aseptate rhabdosome with thecae resembling those typical of Anticostia was found in the oolitic carbonate-rich bed of the Podoli Iron Ore "Horizon" at Praha-Braník (Pod Zemankou Street). The fragment has its basal part covered inside the rock and is fully three-dimensionally preserved. The mode of preservation makes determination difficult because characteristic features are not visible and biometric features are not comparable with those of flattened specimens. However, recalculated parameters are similar. Thus, it is classified as A. teres?. The occurrence of this specimen supports inferrences that the stratigraphic range of $A$. teres begins in the lower part of the Králův Dvưr Formation, possibly at 
the base of the unit since this iron ore "horizon" is locally developed at the base of the formation.

Occurrence. - Lejškov, probably Praha-Baník and old material from Králův Dvůr; lower part of the Králův Dvůr Formation. The species has been recorded only in the Prague Basin, but material collected from the Fjäka Shale at Gulleråsen, in the Dalarna region of central Sweden by S.L. Törnquist (held in the collections of Lund University) includes several specimens that closely resemble A. teres (unpublished observation of C.E. Mitchell). D. Goldman \& CEM (unpublished observations) have recently discovered numerous speciemens of $A$. teres in the lower part of the Pleurograptus linearis Zone of the Dicellograptus Shales at Laeså, Bornholm (see Hadding 1915, Bruvo 2005, for information on the site and its graptolite fauna, which is currently under revision by Goldman and Mitchell). These specimens agree with $A$. teres in all respects (rhabdosome form, thecal apertures, spacing and proximal structure, including the presence of spines on both th $1^{1}$ and th $1^{2}$ ). At Laeså, A. teres is associated with Styracograptus styloideus (Elles \& Wood, 1906) and Normalograptus angustus, among other graptolites.

Family Lasiograptidae Lapworth, 1879, emend. Mitchell, 1987

\section{Genus Paraplegmatograptus Mu, 1963}

Type species. - Paraplegmatograptus uniformis $\mathrm{Mu}$ in Wang, 1978, p. 210, pl. 51, figs 1, 2; subsequently designated by Mu \& Lin 1984, p. 66.

\section{Paraplegmatograptus uniformis Mu in Wang, 1978} Figures 6D, 11D

1978 Paraplegmatograptus uniformis Mu. - Wang (in Stratigraphy Research Group of the Yangtze Gorges, Hubei Bureau of Geology), p. 210, pl. 51, figs 1, 2, non pl. 50, fig. 12 .

1978 Paraplegmatograptus gracilis Mu. - Wang (in Stratigraphy Research Group of the Yangtze Gorges, Hubei Bureau of Geology), p. 209, pl. 51, fig. 11.

1982 Plegmatograptus? craticulus sp. nov.; Williams, pp. 44-45 (partim), text-fig. 13a, h-k, non text-fig. 13g (text-fig. 13b-f, 1 uncertain).

1983 Paraplegmatograptus uniformis Mu. - Wang et al., pl. 4 , fig. 3.

1983 Paraplegmatograptus gracilis $\mathrm{Mu}$. - Wang et al., pl. 3, fig. 10; pl. 11, fig. 4 .

1984 Paraplegmatograptus uniformis Mu. - Mu \& Lin, pp. 65-66, pl. 7, fig. 3.
1984 Paraplegmatograptus uniformis Mu. - Li, p. 502, pl. 92, fig. 14.

1989 Plegmatograptus (?) chuchlensis Přibyl. - Štorch \& Mergl, pl. 4, fig. 1.

1989 Paraplegmatograptus? chuchlensis Přibyl. - Štorch, pp. 183-184 (partim), pl. 1, figs 3, 7, text-fig. 3A, B.

1993 Paraplegmatograptus uniformis $\mathrm{Mu} .-\mathrm{Mu}$ in $\mathrm{Mu}$ et al., pp. 240-241, pl. 53, fig. 9; pl. 55, figs 5-7; pl. 56, figs 1,2 ; text-fig. $44 \mathrm{a}-\mathrm{c}$.

1993 Paraplegmatograptus gracilis $\mathrm{Mu}$ - $-\mathrm{Mu}$ in $\mathrm{Mu}$ et al., pp. 241, pl. 56, figs 3-8, text-fig. 45a-c.

1993 Paraplegmatograptus formosus $\mathrm{Mu} .-\mathrm{Mu}$ in $\mathrm{Mu}$ et al., pp. 241-242, pl. 57, figs 1-4; p. 59, fig. 7; pl. 60, fig. 1 ; text-fig. $46 \mathrm{a}-\mathrm{c}$.

2011 Paraplegmatograptus uniformis $\mathrm{Mu}$ in Wang, 1978. Štorch et al., p. 349, figs 16A, C, Q, 20F, L-M.

Holotype. - Not traced.

Material. - Two incomplete flattened rhabdosomes (CGS PŠ320, PŠ321) in respective sub-scalariform and slightly oblique orientations, solitary on bedding planes, figured by Štorch (1989) in figs 3A, B, respectively.

Description. - The longer rhabdosome attains length of $12.9 \mathrm{~mm}$. Sicula, nema and thecal details not visible in the specimens. In both fragments only reticulum and lacinia are preserved, clathria cannot be identified with certainty. The box-flattened, more complete rhabdosome (Figs 6D, 11D) is more than $1.0 \mathrm{~mm}$ wide at its proximal end where only reticulum is preserved. The more or less planar reticulum widens gradually to $1.65 \mathrm{~mm}$ at the first visible lacinial strand. Overall width is $2.9 \mathrm{~mm}$, including lacinia at this level. Rhabdosome $3.7 \mathrm{~mm}$ wide distally with $2.1-2.15 \mathrm{~mm}$ wide reticulum. Reticulum in measurable portions of the second specimen $2.6 \mathrm{~mm}$ wide proximally and $3.2-3.5 \mathrm{~mm}$ in distal part. Loops marking thecal apertures separated by lacinial loops of similar appearance such that apertures alternate with similarly shaped lacinial orifices. Distance between main sub-horizontal apertural/lacinial loops varies from 0.65 to $0.9 \mathrm{~mm}$; inferred mesial 2TRD: 1.5 to $1.65 \mathrm{~mm}$ and density approximately 12.5 thecae in $10 \mathrm{~mm}$. Width of lacinia depends on rhabdosome orientation being $0.6-0.8 \mathrm{~mm}$ and $1.0-1.15 \mathrm{~mm}$ in individual specimens. Lacinial lists are slender, 0.03-0.04 mm wide. Reticular bars are thinner at the proximal end $(0.02-0.025 \mathrm{~mm})$ and become thicker $(0.03-0.04 \mathrm{~mm}$, exceptionally $0.05 \mathrm{~mm})$ in mid and distal regions. Reticulum exhibits polygonal to almost circular openings. Diameter of openings variable: $0.25-0.7 \mathrm{~mm}$ throughout, however, $0.25-0.5 \mathrm{~mm}$ prevail in proximal whilst $0.35-0.7 \mathrm{~mm}$ in distal parts.

Remarks. - Štorch (1989) revised Plegmatograptus? (= Phormograptus herein) chuchlensis Přibyl, 1949. He 


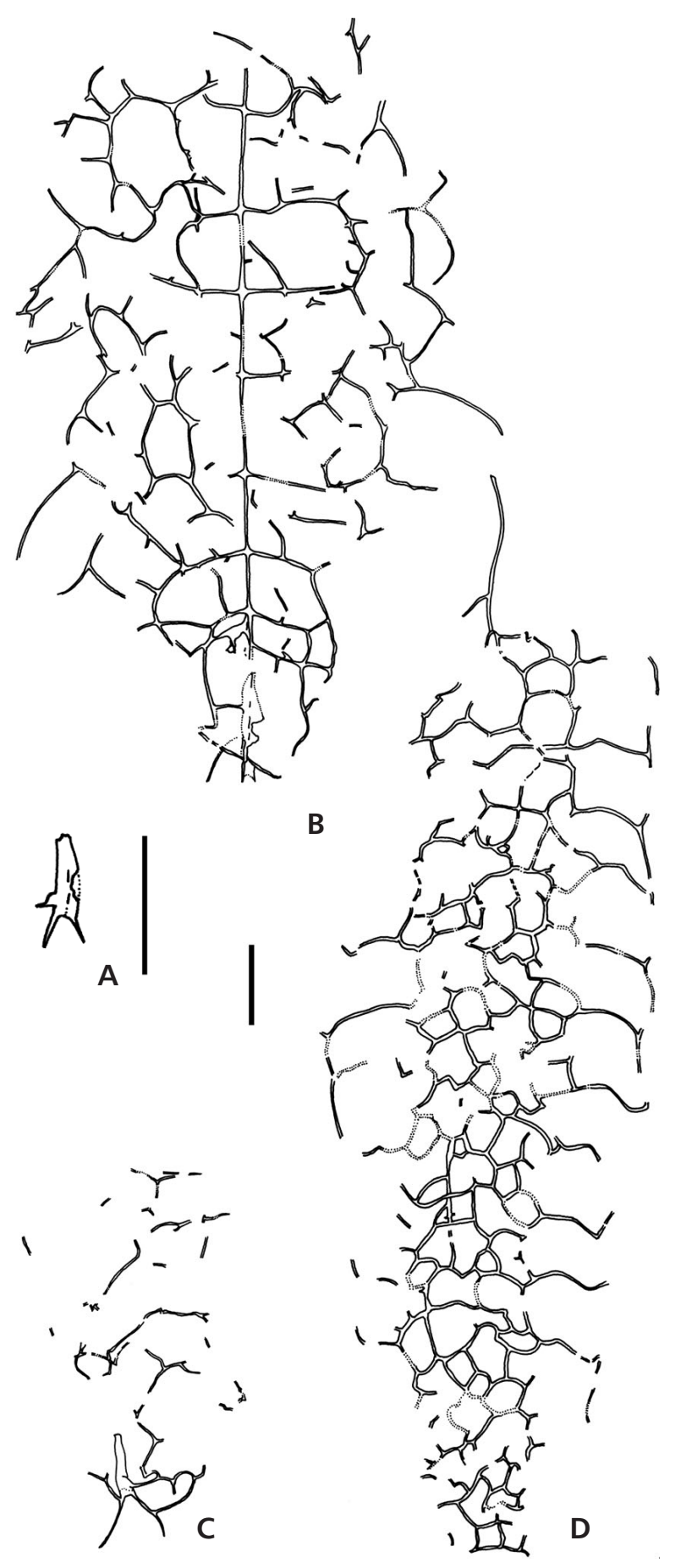

Figure 6. A-C - Phormograptus chuchlensis (Přibyl, 1949): A, C - NM L27762 (A - sicula, C - subscalariform view); B - NM L31783 (holotype). - D - Paraplegmatograptus uniformis Mu in Wang, 1978: CGS PŠ 321, specimen figured by Štorch (1989, fig. 3B). A-C from Praha-Velká Chuchle, D from Liteň. Scale bars equal $1 \mathrm{~mm}$.

included three principal specimens and several fragments in the material referred to that species. One specimen was Přibyl's (1949) holotype and two specimens, both figured, were from his new material, one of which is re-illustrated here
(Figs 6D, 11D). Despite very limited material and unfavorable preservation of lasiograptids in the Králův Dvůr Formation, new insights into lasiograptid morphology (see Štorch et al. 2011) allow for substantial reclassification of these rhabdosomes. The two specimens figured by Storch (1989, figs 3A, B) can be assigned to Paraplegmatograptus uniformis whereas the other material belongs to Phormograptus chuchlensis. Colonies of Paraplegmatograptus are characterized by a complex planar reticulum that forms the obverse and reverse walls of the colony and a relatively simple lacinia connected only to the thecal margins (lateral strands) and thecal apertures. Internally the nema is free from any structural connection to the thecal frame/reticulum. In contrast, as Štorch et al. (2011, pp. 346-348) noted, Phormograptus rhabdosomes have a strongly reduced thecal frame that lacks a well defined reticulum but is regularly connected to the nema by crossbars (e.g., Figs 6B, 11H) and possess a deep, complex lacinial mesh that entirely surrounds the rhabdosome, including its obverse and reverse sides. The determination that two studied specimens belong to Parap. uniformis is based on the concordance of dimensions, character of the lacinia and the presence of a dense reticulum. Because of the preservation in the available material, these specimens of Parap. uniformis also resemble some specimens of Plegmatograptus Elles \& Wood, 1908, especially those of its type species, P. nebula Elles \& Wood, 1908. However, P. nebula exhibits a more slender rhabdosome and distinctly finer reticulum, as noted by Štorch (1989). Additionally, colonies of P. nebula combine the deep, all-encompassing lacinia seen in Phormograptus with a well-developed clathrium that bears a planar reticulum (Štorch et al. 2011).

Occurrence. - Liteň; upper Králův Dvůr Formation. The species appears to be widely distributed being recorded from South China, eastern Laurentia (southern Scotland), western Laurentia (Nevada) and northern Gondwana (Bohemia).

\section{Genus Phormograptus Whittington, 1955}

Type species. - Phormograptus sooneri Whittington, 1955; pp. 847-850, pl. 83, figs 4, 5; text-figs 15-19; by original designation.

\section{Phormograptus chuchlensis (Přibyl, 1949)}

Figures 6A-C, 11H

1949 Plegmatograptus(?) chuchlensis nov. spec.; Přibyl, pp. 35-37, text-figs $1,2$.

non 1974 Arachniograptus chuchlensis (Přibyl). - Obut \& Sobolevskaya, p. 118, pl. 43, fig. 17.

?1978 Paraplegmatograptus connectus Mu; Wang (in Stratigraphy Research Group of the Yangtze Gor- 
ges, Hubei Bureau of Geology), p. 209, pl. 51, figs 3,4 .

?1984 Paraplegmatograptus cf. chuchlensis (Přibyl). - Li, p. 189 , pl. 15 , fig. 9.

1989 Plegmatograptus? chuchlensis Přibyl. - Štorch, pp. 183-184 (partim), non pl. 1, figs 3, 7, non text-fig. 3A-B

?1993 Paraplegmatograptus connectus $\mathrm{Mu}$. - Mu in $\mathrm{Mu}$ et al., pp. 243-244, pl. 57, figs 5, 6, 8; pl. 58, figs 1-3; pl. 60 , fig. 2 ; pl. 61 , figs $1-4$; text-fig. $47 \mathrm{a}$, b.

?2011 Arachniograptus chuchlensis (Přibyl). - Sobolevskaya, p. 127 , pl. 25, figs 4,5 .

?2011 Phormograptus connectus (Mu), Štorch et al., pp. 350-352, figs 16B, E, F, 20B-E, H, K (see for further synonymy).

Holotype. - Specimen NM L31783 from Praha-Velká Chuchle - slope above the hippodrome, designated and figured by Přibyl (1949) text-fig. 1a, b.

Material. - Two incomplete rhabdosomes with traceable clathria and lacinia (NM L27762, L31783, subscalariform and scalariform views, respectively) and one individual sicula (NM L27762) were studied. In addition, several fragments of undifferentiated parts of mesh were found. Several such fragments are associated with the Ph. chuchlensis holotype together with specimens of Normalograptus angustus, and one fragment was encountered on another slab with four rhabdosomes of $N$. angustus (NM without number).

Description. - Maximum length of the largest incomplete rhabdosome is $10.5 \mathrm{~mm}$ (Figs 6B, 11H). In scalariform view, the narrow sicular region rapidly widens from $1.15 \mathrm{~mm}$ near sicular aperture to $2.5 \mathrm{~mm}$ at third theca, above the sicular apex. Maximum width of $5.45 \mathrm{~mm}$ attained around th5-th6. Sicula slender, straight or slightly bent, only $0.15-0.20 \mathrm{~mm}$ wide at the aperture. An incomplete sicula is $0.65-0.85 \mathrm{~mm}$ long; in one specimen it seems to be almost complete and $1.25 \mathrm{~mm}$ long. Virgella robust, straight to slightly curved, 0.5 to slightly more than $1.0 \mathrm{~mm}$ long. Antivirgellar spines seen in one specimen are antero-dorsally oriented, $0.35-0.8 \mathrm{~mm}$ long. Th $1^{1}$ buds near the sicular aperture; forms minute fusellar prothecal hood above the sicular foramen. This part has its dorsal edge $0.2-0.25 \mathrm{~mm}$ above the sicular aperture and its opening is $c a 0.05 \mathrm{~mm}$ above the same. Thus, the preserved th $1^{1}$ protheca is $0.15-0.2 \mathrm{~mm}$ long and $0.1 \mathrm{~mm}$ wide at the opening (Fig. 6A). Framework of th $1^{1}$ continues with a $0.4 \mathrm{~mm}$ long median ventral list that arcs gently out from base of virgella and terminates in apertural loop (Fig. 6C). Structure of th $1^{2}$ not clearly visible. Clathria composed of well developed dorsal and apertural lists along with segments of the apertural spine and lacinia. All the structures are arranged along prominent straight nema and supported by well developed crossbars. Crossbars straight, perpendicular or almost perpendicular to the nema, diverging at one point to both obverse and reverse directions, linking dorsal lists of inner thecal framework (first node outwards) and, beyond that, pleural threads of lacinia (Fig. 6B). Crossbar spacing is variable. Except for the first pair of rods, which are $0.75 \mathrm{~mm}$ apart, next crossbars irregularly spaced at $0.95-1.25 \mathrm{~mm}$, with most values near the minimum and maximum of this range and repeating irregularly. Clathria is enfolded by prominent, sparse lacinia. Lacinial mesh composed of polygonal openings of variable sizes, but mostly large, some around $1 \mathrm{~mm}$, developed especially on the obverse and reverse sides. Lacinia reduced in sicular region, and widens notably above sicula, i.e. from second thecal pair. Linear structural units of the colony are all of similar thickness. Differences are only slight in absolute values: nema is the most robust, being $0.03-0.04 \mathrm{~mm}$ wide, crossbars are slightly thinner, reaching $0.03-0.035 \mathrm{~mm}$, and main lists and bars of clathria and lacinia are $0.02 \mathrm{~mm}$ wide. Based on measurement of dorsal lists and transversal rods, 2TRD is $2.1-2.3 \mathrm{~mm}$ (exceptionally $1.7 \mathrm{~mm}$ ) in region above sicula, thecae number $9.5-11.5$ in $10 \mathrm{~mm}$.

Remarks. - The proximal clathria fits well with the original diagnosis of the genus by Whittington (1955), based on the well-preserved type species Ph. sooneri Whittington, 1955. Our material resembles the type species also in the dimensions of the sicula, sicular spines and width of the proximal end. The size of the rhabdosome and its width in respective portions, as well as thecal spacing and architecture of Ph. chuchlensis, all match those of Ph. connectus (Mu in Wang, 1978). Thus, it appears likely that the material referred to Ph. connectus belongs to Ph. chuchlensis. All the differences between these taxa are fully attributable to preservational artifacts, which strongly affect the density of the lacinial mesh and the configuration of thecal framework elements (see Štorch et al. 2011 for a detailed discussion). Nevertheless, the material upon which $P h$. chuchlensis is based is very incomplete and exceptionally rare. Thus, although the name Plegmatograptus(?) chuchlensis Prribyl, 1949, has clear priority, we hesitate to refer Ph. connectus to Ph. chuchlensis; that is, to replace such a well-known and widely distributed taxon by another that is comparatively poorly known and difficult to study further in its type area.

Occurrence. - Králův Dvůr, Praha-Velká Chuchle; upper Králův Dvůr Formation.

Material referred to $P h$. connectus is widely known in late Katian strata (Dicellograptus complexus and Paraorthograptus pacificus zones) outside Bohemia, including several regions in South China, the western United States, NW Canada, and Scotland where it is a regular element of the late Katian Dicellograptus complexus and 
Paraorthograptus pacificus zones faunas or their local equivalents. Material reported as Arachniograptus chuchlensis (Sobolevskaya, 2011) from Taimyr may also represent this species as well as specimens of Arachniograptus sp. from Kazakhstan (Apollonov et al. 1980) and Siberia (Koren' et al. 1983), and also the material that Brussa et al. (2003) reported as Plegmatograptus sp.

Superfamily Climacograptoidea Frech, 1897; emend Mitchell et al., 2007

Family Climacograptidae Frech, 1897

\section{Genus Styracograptus Štorch et al., 2011}

Type species. - Climacograptus tubuliferus Lapworth, 1876; by original designation.

\section{Styracograptus lobatus (Perner, 1895)}

Figures 7B-D, I; 12B-D

1895 Diplograptus (Glyptograptus) lobatus n. sp.; Perner, p. 28 , pl. 7., fig. 15 ; non pl. 8 , fig. 15 [= Normalograptus angustus (Perner, 1895)].

1949 Climacograptus angustus (Perner). - Přibyl, pp. 7-9 (partim).

Holotype. - Specimen NM L27532 in scalariform view from Králův Dvůr (Königshof) figured by Perner (1895), pl. 7, fig. 15; by monotypy. Two specimens were included in the original description; as one belongs to a different species it is no longer a syntype because it is not a component of the name-bearing type; the remaining single specimen becomes a holotype.

Material. - Four incomplete, solitary rhabdosomes (NM L27532, WBM S 05149, S 06566, S 06567).

Description. - Medium-sized, aseptate rhabdosome, maximum $26.5 \mathrm{~mm}$ long; proximal end only slightly asymmetric, rounded and relatively narrow. Widens from 0.7 to $0.85 \mathrm{~mm}$ at first thecal pair, through $0.9-1.0 \mathrm{~mm}$ at the second, $1.05-1.25 \mathrm{~mm}$ at third, to $1.2-1.35 \mathrm{~mm}$ at fifth thecal pair and attains the maximum width of $1.6-1.7 \mathrm{~mm}$ at ca $12^{\text {th }}$ thecal pair. Maximum width in scalariform view is $1.8 \mathrm{~mm}$. From values of width in lateral and scalariform orientations, and from length of apertures and depth of apertural excavations, a sub-rectangular to even rounded square cross-section can be inferred. Crossbars and slender nema observed in some specimens (Fig. 7B, I). Sicula about $1.5 \mathrm{~mm}$ long, with aperture $0.2 \mathrm{~mm}$ wide. Virgella $1.15 \mathrm{~mm}$ long, relatively wide at its base, slightly deflexed across sicular aperture. Ventral wall of upwardgrown portion of th $1^{1}$ forms a rounded arc $0.40-0.55 \mathrm{~mm}$ long. Th $1^{2}$ crosses sicular outline near sicular aperture and reaches $0.6-1.0 \mathrm{~mm}$ in length. Subsequent thecae with strong angular genicula; supragenicular walls usually slightly convex, subparallel to rhabdosome axis; $0.5-0.7 \mathrm{~mm}$ long proximally and $0.6-0.9 \mathrm{~mm}$ long distally. Thecal density decreases from $12-14.5$ thecae in $10 \mathrm{~mm}$ proximally to $9.5-10$ distally. Accordingly, 2TRD increases from $1.2-1.3 \mathrm{~mm}$ at th2, through $1.5-1.75 \mathrm{~mm}$ at th5, and $1.6-1.8 \mathrm{~mm}$ at th10 to the maximum 2.05 to $2.1 \mathrm{~mm}$. Thecal excavations small, proximally 0.1 to $0.2 \mathrm{~mm}$ high, $0.1-0.15 \mathrm{~mm}$ deep and distally $0.2-0.3 \mathrm{~mm}$ high, $0.15-0.2 \mathrm{~mm}$ deep, semicircular in profile. The whole excavation, including thecal aperture and geniculum of next theca, possesses a $0.015-0.03 \mathrm{~mm}$ wide selvage. Thecal excavations in the second series [i.e., $\left.\operatorname{th}(n)^{2}\right]$ situated against lower half of supragenicular portion of the opposite th $(n+1)^{1}$. In the scalariform oriented holotype rhabdosome (Fig. 12B), thecal excavations have narrow-ellipsoidal shape, $0.7-0.85 \mathrm{~mm}$ wide proximally, widen to $0.9-1.0 \mathrm{~mm}$ in the middle part of the rhabdosome and then narrow to the width of $0.8-0.85$ distally. Width/height ratio of aperture 2.6-6.1 (mean $=4.6$ ). These ratios show decreasing trend of values from proximal to distal end with maximum values recorded in mid part of the rhabdosome. However, apertural shape differences along the colony may be affected by preservational artifacts.

Remarks. - Perner (1895) described this species based on a single scalariform rhabdosome NM L27532 and a small slab bearing two clearly- and one faintly-preserved specimens (NM L27537 and its counterpart NM L27986). He figured the scalariform rhabdosome on pl. 7, fig. 15 and the shorter one of the two distinct rhabdosomes on pl. 8, fig. 15. Přibyl (1949) synonymized S. lobatus with Climacograptus angustus (now Normalograptus angustus) and refigured the latter specimen on his pl. 2, fig. 7. Přibyl's (1949) assignment of the latter specimen to N. angustus is correct. In addition, the second (longer) clearly preserved rhabdosome on the same slab can be also assigned to $N$. angustus. The only questionable specimen is a faintly preserved, laterally flattened distal fragment, that was neither described nor figured by Perner (1895) or Přibyl (1949). It displays some similarities in its thecal excavations, although its preservation is too poor for positive identification. On the other hand, Prribyl (1949) misinterpreted the scalariform specimen that exhibits features sufficient for its differentiation from $N$. angustus, especially the thecal excavations and general robustness of the rhabdosome. Whereas the two distinct subscalariform specimens on the slab NM L27537 exhibit rather high, narrow, open, oval excavations and slightly inclined supragenicular walls, the scalariform specimen NM L27532 possesses low, wide, slit-like excavations showing very different width/height 

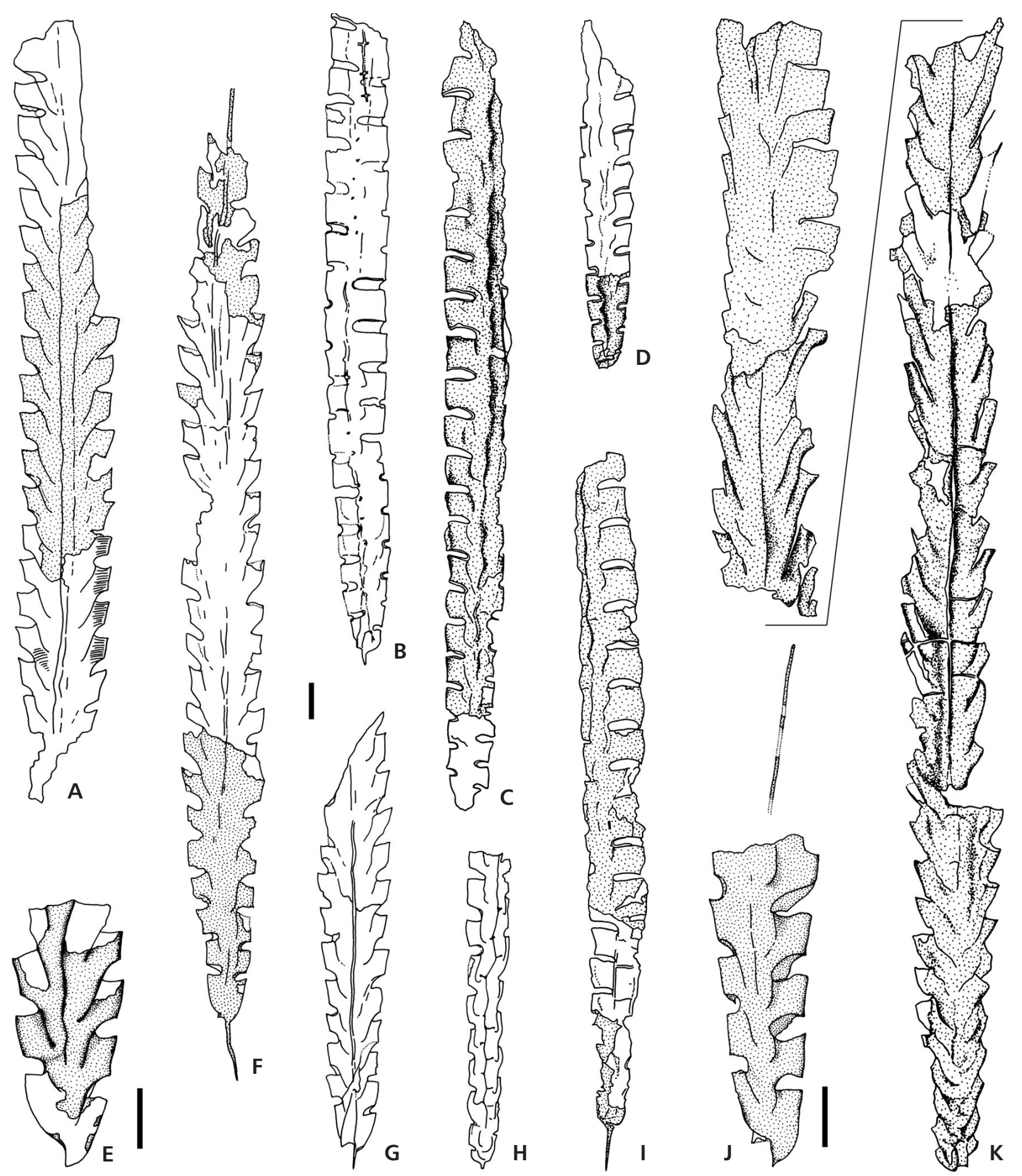

Figure 7. A, E-G, J-Metabolograptus ojsuensis (Koren'\& Mikhaylova in Apollonov et al., 1980): A - CGS PŠ 1163 (low relief specimen, partly exfoliated); E - CGS PŠ 1168 (partial relief reverse view, juvenile rhabdosome); F - WBM S 05153 (flattened, partly exfoliated rhabdosome); G - CGS PŠ 1170 (obverse proximal part preserved in relief); J - CGS PŠ 1167 (flattened juvenile rhabdosome). • B-D, I - Styracograptus lobatus (Perner, 1895): B - WBM S 05149 (low relief specimen in subscalariform view); C - WBM S 06566 (low relief subscalariform specimen, with exfoliated proximal portion); D - WBM S 06566 (partial counterpart of C); I - WBM S 06567 (subscalariform flattened specimen). • H - Styracograptus sp.: WBM S 05150 (full relief external mold proximally, becoming compressed distally). $\bullet \mathrm{K}$ - Diplograptus fritschi Perner, 1895 : WBM S 05155 (mature rhabdosome preserved in low relief, distal part continues as indicated). A, E-G, J from Zadní Třebaň; B, H from Vráž - D5 highway exit 14 (lower in the slope); C, D, I from Svinaře; K from Praha (probablyVršovice). Figures A-D, F-I, K × 6, figures E, J × 10. Scale bars equal 1 mm. 
ratio in comparison with that of $N$. angustus. Recent finds of several rhabdosomes proved the existence of $S$. lobatus that can be distinguished from $N$. angustus by its strongly geniculate, more densely spaced thecae and shallow, slit-like apertural excavations with longer apertural margins and high width/height ratios. The proximal end of S. lobatus is blunt, heavily sclerotized and almost symmetrical. Like other species of Styracograptus, S. lobatus bears nema crossbars at the base of the interthecal septa, which also helps to distinguish it from $N$. angustus, and is an especially useful feature in scalariform to subscalariform view. Thus, only the scalariform specimen from type series actually belongs to S. lobatus and so becomes the holotype by monotypy despite its preservation in an unfortunate orientation.

S. lobatus can be unequivocally distinguished from other biserial taxa of the Králův Dvůr Fm. by its slit-like apertural excavations combined with its styracograpid rhabdosome and by other, mainly biometric features. S. lobatus differs from the equally robust Styracograptus styloideus (Elles \& Wood, 1906) only by its slightly narrower rhabdosome with more densely spaced thecae. From another, similarly large species Styracograptus mississippiensis (Ruedemann, 1908), S. lobatus can be distinguished by less prominent, more gradual widening of the rhabdosome and narrower, more closed, symmetric apertural excavations. S. lobatus can be readily distinguished also from Styracograptus putillus (Hall, 1865) (= Pseudoclimacograptus clevensis Skoglund, 1963; see Goldman \& Bergström, 1997, which is probably also synonymous with Pseudoclimacograptus chiai Mu, 1949), which possesses a zig-zag median septum, is slightly narrower throughout and has more open apertural excavations relative to its rather short supragenicular thecal walls.

Occurrence. - Králův Dvůr (historical material, type specimen), Vráž - D5 highway exit 14 (low in the slope, one specimen), Svinaře (two specimens); lower and probably middle parts of the Králův Dvůr Formation. The species has been recorded only from Bohemia.

\section{Styracograptus sp.}

Figures 7H, 11C

Material. - Single oblique-oriented specimen preserved in relief (WBM S 05150).

Description. - The only available specimen $7.3 \mathrm{~mm}$ long, preserved in relief but slightly distorted due to oblique reverse orientation on the bedding plane. Rhabdosome with prominent zig-zag septum, $0.73 \mathrm{~mm}$ wide at first thecal pair, widens slowly through $0.86 \mathrm{~mm}$ at second pair, 0.9-0.95 at third and fifth pairs to maximum $1.2 \mathrm{~mm}$ at eighth thecal pair. Proximal end narrow, rounded, and seems to be almost symmetrical. Upward-grown portion of th $1^{1}$ at least $0.35 \mathrm{~mm}$ long. Th $1^{2}$ crosses sicula nearly horizontally above its oblique aperture leaving a short, toothlike free dorsal part of the sicula. Th $1^{2}$ turns up in a wide bend immediately distal from its crossing canal portion. Th $1^{2} 0.75 \mathrm{~mm}$ long, gives rise to a dicalycal th $2^{2}$. Thecae of climacograptid type with angular genicula. Length of their supragenicular walls range between 0.65 and $0.8 \mathrm{~mm}$. Thecal excavations $0.2 \mathrm{~mm}$ high (exceptionally $0.4 \mathrm{~mm}$ ), rimmed by tiny, thickened lips. 2TRD at th2 $1.4 \mathrm{~mm}$ increasing rapidly to $1.75-1.95 \mathrm{~mm}$ at th5. Thecae number 11.5 in $10 \mathrm{~mm}$ in proximal part.

Remarks. - The rhabdosome may be referred to Styracograptus because of its simple, rounded proximal end without any antivirgellar and thecal spines and climacograptid, sharply geniculate thecae. Septal cross-bars express themselves in small pits visible along the axial part of the lateral wall of the rhabdosome. The zig-zag line in the axial part of the lateral wall, however, indicates the presence of a Pseudoclimacograptus-like septum. The subscalariform orientation of the rhabdosome partly obscures some critical features such as the thecal style (particularly sharpness of the geniculum), apertural excavations and details of the proximal end. In addition, the specimen is the only climacograptid from the Králův Dvůr Formation that is preserved in relief. As the other specimens assigned to that group, which all belong to Styracograptus lobatus, are flattened, the differences in preservation do not allow more detailed comparisons of the preserved features. Despite the high variability of $S$. lobatus, the present specimen differs especially in thecal parameters, having longer supragenicular walls, wider thecal spacing (higher 2TRD in proximal part) and possibly a narrower distal colony width and strongly zigzag median septum. In all these respects the present form strongly resembles Styracograptus putillus (Hall, 1865 ) (for comment on its synonyms see above). Considering the mentioned uncertainties and the fact that we have only a single specimen for study, we leave this taxon in open nomenclature.

Occurrence. - Vráž - D5 highway exit 14 (lower in the slope); lower Králův Dvůr Formation.

Infraorder Neograptina Štorch et al., 2011

Family Normalograptidae Štorch \& Serpagli, 1993, emend. Melchin et al., 2011

Genus Normalograptus Legrand, 1987, emend. Melchin et al., 2011

Type species. - Climacograptus scalaris var. normalis Lapworth, 1877, p. 138, pl. 6, fig. 31; by original designation. 


\begin{tabular}{|c|c|c|c|c|c|c|c|c|c|}
\hline \multirow{2}{*}{$\begin{array}{l}\text { Specimen } \\
\text { No. }\end{array}$} & \multirow[t]{2}{*}{ Figures } & \multicolumn{4}{|c|}{ W } & \multicolumn{4}{|c|}{ 2TRD } \\
\hline & & th1 & th3 & th5 & th10 & th2 & th5 & th10 & dist. th \\
\hline NM L27507 & (Přibyl 1949, pl. 2, fig. 6) & 0.9 & 0.95 & 1.0 & 1.0 & 1.75 & 1.85 & 2.0 & - \\
\hline NM L31788 & $9 \mathrm{~A}$ & 0.9 & 0.95 & - & - & 1.75 & - & - & - \\
\hline NM L31788 & $9 \mathrm{D}$ & 0.95 & 1.05 & 1.15 & 1.25 & 1.6 & 1.9 & - & - \\
\hline NM L31797 & $13 \mathrm{~B}$ & 0.95 & 1.05 & 1.1 & - & 1.65 & - & - & - \\
\hline NM L31798 & $13 \mathrm{~F}$ & 0.9 & 0.95 & 0.95 & 1.05 & 1.95 & 2.0 & 2.2 & 2.2 \\
\hline NM L40984 & $9 \mathrm{E}$ & 0.85 & 0.95 & 1.05 & - & 1.35 & 1.8 & - & - \\
\hline NM L40985 & $9 \mathrm{~F}$ & 1.0 & - & 1.2 & - & 1.7 & 2.05 & - & 2.2 \\
\hline FSCU PK 24 & $9 \mathrm{~B}$ & 0.85 & - & 0.95 & - & 1.5 & - & - & - \\
\hline FSCU PK 28 & $9 \mathrm{C}, 13 \mathrm{G}$ & 0.95 & 1.0 & - & - & 1.75 & 2.0 & - & - \\
\hline
\end{tabular}

Table 4. Normalograptus angustus (Perner, 1895). Dimensions of illustrated, type and other selected specimens (in $\mathrm{mm}$ ); W - width. References of previously figured specimens mentioned in the text and explanation of figures.

\section{Normalograptus angustus (Perner, 1895)}

Figures 8A, B, 9A-F, 13B, F, G

1895 Diplograptus (Glyptograptus) euglyphus Lapworth var. angustus mihi; Perner, p. 27, pl. 8, figs 1, 14a, b.

1895 Diplograptus (Glyptograptus) lobatus n. sp.; Perner, p. 28 (partim), pl. 8, fig. 15 .

1949 Climacograptus angustus (Perner). - Přibyl, pp. 7-10, pl. 2, figs 2-9.

1963 Climacograptus angustus (Perner). - Skoglund, pp. 40-42, pl. 3, figs 1, 2, 4-6; pl. 4, fig. 7, pl. 5, fig. 6 .

1983 Climacograptus angustus (Perner). - Koren’ \& Sobolevskaya in Koren' et al., pp. 106-108, pl. 27, figs 1-5, text-fig. 34 .

1989 Climacograptus angustus (Perner). - S̆torch \& Mergl, pl. 4, figs 3, 4.

1989 Scalarigraptus angustus (Perner). - Štorch, pp. 178-181, pl. 2, figs 3-5, 8, text-fig. 2E-J.

2005 Normalograptus angustus (Perner). - Chen et al., pp. 252-255, text-fig. 5D, I, K, Q, DD.

2007 Normalograptus angustus (Perner). - Loydell, pp. 30, 32-33, pl. 1, fig. 3, text-fig. 15L, M.

2011 Normalograptus angustus (Perner). - Štorch et al., p. 369 , figs $25 \mathrm{G}, \mathrm{Q}, 26 \mathrm{H}$.

Holotype. - Specimen NM L27552 from KrálůV Dvůr (Königshof) figured as incomplete rhabdosome by Perner (1895), pl. 8, figs 14a, b and refigured complete by Přibyl (1949), pl. 2, fig. 8; designated by Přibyl (1949) by monotypy.

Štorch (1989) mentioned and Loydell (2007) also figured specimen NM L27507 as the holotype. Although in type collection of J. Perner, this specimen has never been figured by him but by Přibyl (1949) pl. 2, fig. 6 for the first time. In addition, this specimen is not marked as original on the label. On the other hand, there is clearly stated on the label of the specimen NM L27552 that it is the original No. 67. This fits the datum in the explanation of pl. 8, fig. 14a, b by Perner (1895).

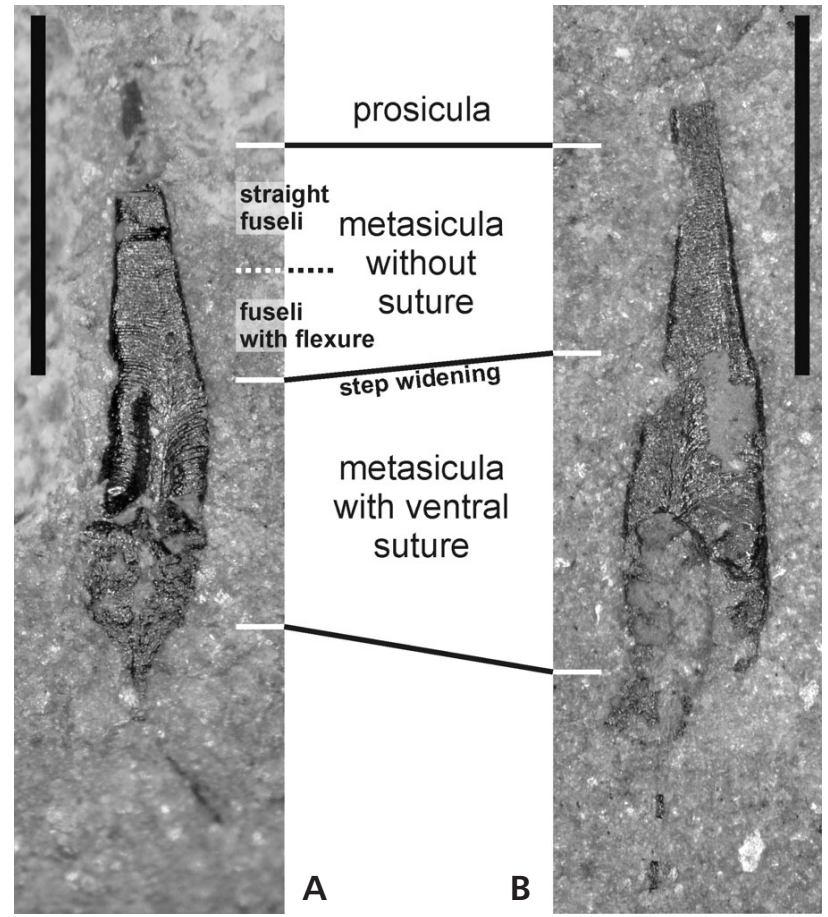

Figure 8. Normalograptus angustus (Perner, 1895), details of siculae: both specimens - NM L31797 from Praha-Velká Chuchle. Scale bars equal $1 \mathrm{~mm}$.

Material. - About 50 specimens studied and measured. The most abundant species known in tens of specimens, which occur either solitary or in small monospecific clusters. At some localities, the rhabdosomes were found clustered with other graptolites (Dicellograptus laticeps or Phormograptus chuchlensis) or shelly debris, especially material of ostracods, rhynchonelliform brachiopods and trilobites.

Description. - Slender, septate rhabdosome, commonly about $10 \mathrm{~mm}$, occasionally up to $20 \mathrm{~mm}$ long; oval to almost circular in cross section. Widens slightly from 0.8 to $0.95 \mathrm{~mm}$ at first thecal pair, through $0.85-1.0 \mathrm{~mm}$ at 

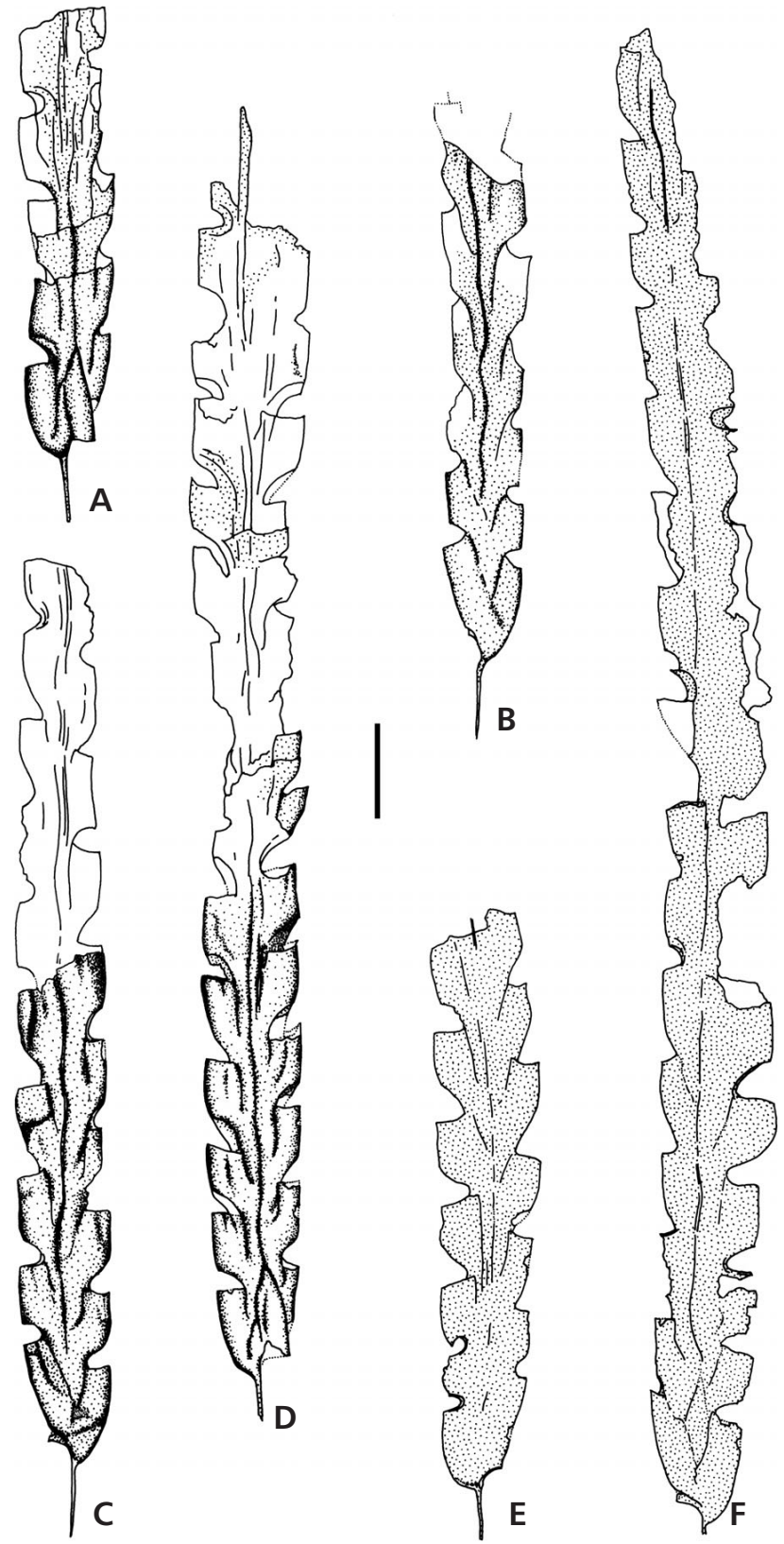

Figure 9. Normalograptus angustus (Perner, 1895): A - NM L31788 (obverse proximal part, preserved in relief); B - FSCU PK 24 (specimen in partial relief, reverse view); C - FSCU PK 28 (reverse proximal part in relief, distal part external mold); D - NM L31788 (specimen preserved in partial relief, obverse view, distal part flattened and exfoliated); E - NM L40984 (flattened rhabdosome); F - NM L40985 (flattened rhabdosome). A, D from Praha-Velká Chuchle; B, E, F from Králův Dvůr; $\mathrm{C}$ from Liteň. All figures $\times 10$, scale bar equals $1 \mathrm{~mm}$.

second pair, and $0.95-1.05 \mathrm{~mm}$ at the third, to 0.95 to $1.15 \mathrm{~mm}$ at the fifth thecal pair. The latter width generally maintained distally but a maximum width of $1.25 \mathrm{~mm}$ recorded at th12 in one specimen.

Rhabdosome exhibits a typical pattern $\mathrm{H}$ proximal structure. Sicula, measured on few juvenile specimens with no theca or only with th $1^{1}, 1.55-2.0 \mathrm{~mm}$ long and 0.25 to $0.4 \mathrm{~mm}$ wide at aperture. Virgella prominent, up to $3.9 \mathrm{~mm}$ (usually $0.5-0.8 \mathrm{~mm}$ ) long. Nema 0.04 to $0.055 \mathrm{~mm}$, exceptionally $0.06 \mathrm{~mm}$, wide. Sicula exposed on obverse side for 1.0-1.05 $\mathrm{mm}$ before becoming enclosed by second thecal pair. Th $1^{1}$ initially grew downward $0.4 \mathrm{~mm}$ along sicula and extended $0.2-0.25 \mathrm{~mm}$ below the sicular aperture, forming $0.6-0.65 \mathrm{~mm}$ long descending portion. Upward grown part sharply turned upward and $1.0-1.05 \mathrm{~mm}$ long (exceptionally 0.9 to $1.2 \mathrm{~mm}$ ). Prosoblastic th $1^{2}$ buds just above the sicular aperture and its crossing canal emerges from dorsal sicular outline 0.1-0.4 $\mathrm{mm}$ above sicular aperture. Upward grown part of the th $1^{2} 0.75-0.95 \mathrm{~mm}$ long. Asymmetric, $\mathrm{V}$-shaped form of the proximal end well visible in reverse view, th $1^{2}$ with slightly, and smoothly, rounded ventral wall (Fig. 9B, C). Subsequent thecae moderately geniculate, 1.25-1.5 mm long, overlapping for one third their length or slightly more. Thecae appear less strongly geniculate, nearly glyptograptid, when preserved as internal molds in relief, in particular those in oblique orientation on the bedding plane. Infragenicular thecal wall short, concave and arched forming an open aperture. Supragenicular walls straight to slightly convex, 0.5 to $0.7 \mathrm{~mm}$ long, parallel to very slightly outwardly inclined. Thecal apertures subhorizontal, often weakly everted and slightly concave, facing markedly asymmetrical apertural excavations. Apertural width $0.25-0.4 \mathrm{~mm}$, maintained in all thecae except narrower th $1^{2}$, which is only $0.2-0.25 \mathrm{~mm}$ wide. Thecae regularly subalternate throughout whole rhabdosome; apertures above th $1^{2}$ situated slightly above geniculum of opposite thecae. Thecal spacing increases from $2 \mathrm{TRD}_{2} 1.6-1.85 \mathrm{~mm}$, through $2 \mathrm{TRD}_{5} 1.85-2.05 \mathrm{~mm}$ to the maximum $2.0-2.2 \mathrm{~mm}$ attained with $2 \mathrm{TRD}_{10}$. Thecae number 10.5-11.5 in $10 \mathrm{~mm}$. In scalariform view, depending on distortion, apertural excavations usually suboval with more vaulted infragenicular and flatter apertural arches but oval to almost circular projections of apertural excavations also present in some specimens. In this view, excavations $0.5-0.6 \mathrm{~mm}$ wide and $0.3-0.4 \mathrm{~mm}$ high; width/height ratio 1.12-2.35 (proving subcircular to prolongated ellipsoid; mean $=1.6$ ) .

Median septum complete, generally slightly undulose in its whole course. It begins from sicular apex, i.e. approximately from the level of aperture of th $1^{2}$, but rarely delayed to the aperture of th $2^{2}$ (Fig. 8B). Th $2^{1}$ dicalycal in the former and th $2^{2}$ in the latter case.

Remarks. - This long-ranging and cosmopolitan species is characterized by its narrow colony with rather widely spaced thecae relative to rhabdosome size, and smooth, unadorned genicula. Other typical features are its parallelsided rhabdosome and slightly protracted proximal end. The morphology of the Bohemian population is conserva- 
tive and biometric variability is quite low. Specimens of Normalograptus normalis (Lapworth, 1877) described by Elles \& Wood (1906) resemble $N$. angustus but most of these belong to Normalograptus ajjeri (Legrand, 1977). True N. normalis is a more robust form (Loydell 2007). $N$. ajjeri is wider than $N$. angustus, also having sligthly more densely spaced thecae. Downward growing portion of its th $1^{1}$ is shorter. Perner (1895, pl. 8, fig. 1) incorrectly figured a distorted fragment of dicellograptid stipe (D. laticeps) as an example of the thecae of $N$. angustus. Pribyl (1949) incorrectly synonymized N. angustus with Styracograptus lobatus (see comment in remarks for that species). Finally, N. angustus has also previously been widely confused with Climacograptus miserabilis Elles \& Wood (1906), which it closely resembles in its colony dimensions, but that species has recently been recognized as a distinct species of Styracograptus on the basis of differences in proximal structure and the presence of nema cross bars at the base of the interthecal septa (Goldman et al. 2011).

Occurrence. - Karlík, Králův Dvůr, Lejškov, Levín, Liteň, Praha-Malá Ohrada, Praha-Nusle, Praha-Radotín - highway tunnel and cut of the road to Třebotov, Praha-Velká Chuchle, Praha-Zličín, Tobolka near Koněprusy - borehole (depths 1118.0 and 1356.6 m), Vráž - D5 highway exit 14 (higher in the slope), Zadní Třebaň; middle (?) and upper Králův Dvůr Formation. It is a cosmopolitan species. In addition to occurrences in northwestern Gondwana (Bohemia), northern Gondwana (Jordan), South China, Avalonia (England), Baltica (central Sweden), Siberia (north-eastern Siberia) and Laurentia (Nevada, southern Scotland) as noted in the synonymy, a further Laurentian occurrence in Arctic Canada was reported by Melchin et al. (2011). Koren' \& Sobolevskaya in Koren' et al. (1983) listed other occurrences from Siberia (Ural-Tianshan belt and Gornyi Altai).

Superfamily Retiolitoidea Lapworth, 1873,

emend. Melchin et al., 2011

Family Neodiplograptidae Melchin et al., 2011

Genus Metabolograptus Obut \& Sennikov, 1985, emend. Melchin et al., 2011

Type species. - Diplograptus modestus sibiricus Obut, 1955, p. 138, pl. 59, figs 5-8; by original designation.

\section{Metabolograptus ojsuensis (Koren' \& Mikhaylova in Apollonov et al., 1980)}

Figures 7A, E-G, J, 13C, D, H-K

1973 Diplograptus tariti Legrand; Mikhaylova, p. 16, pl. 3, figs 7,8 .
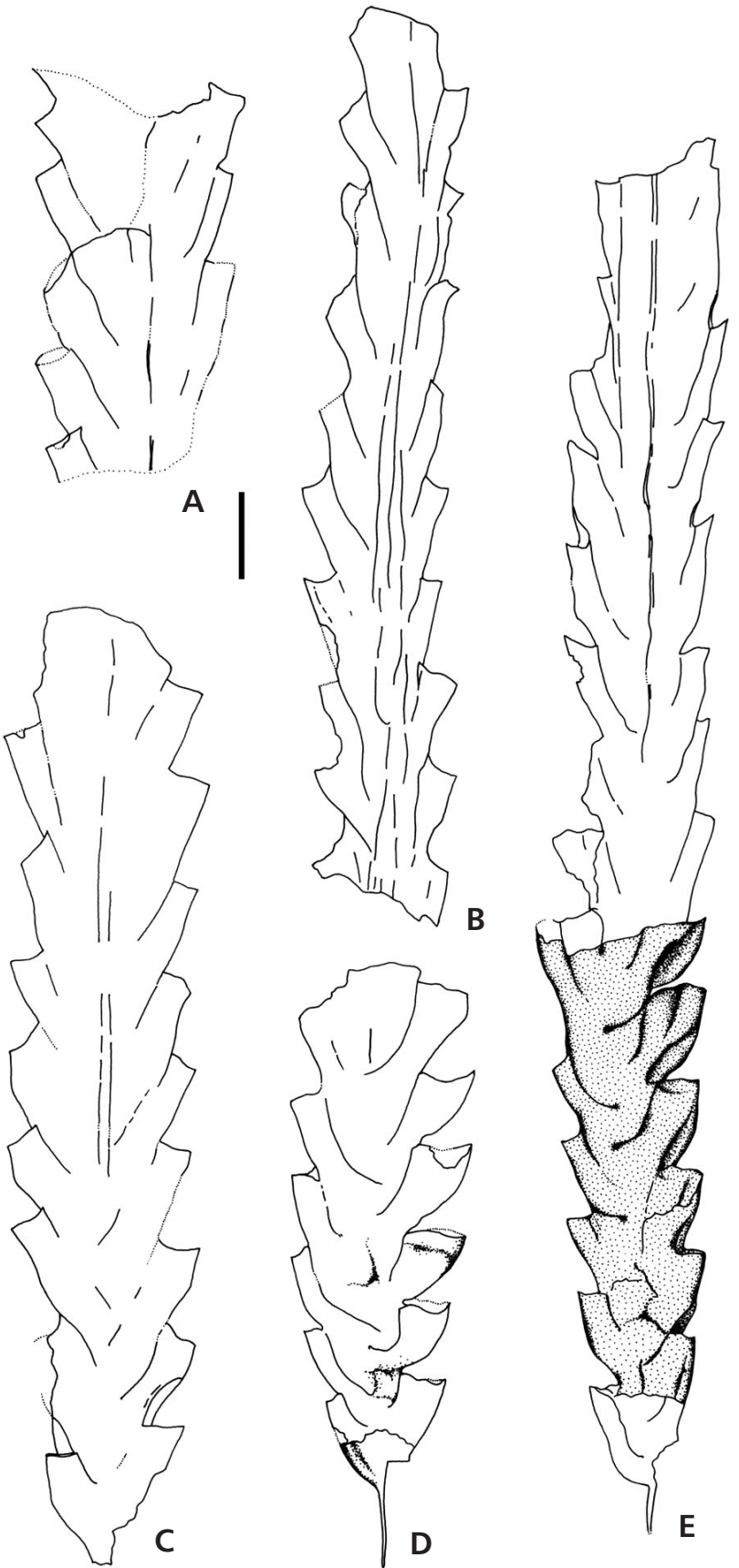

Figure 10. Diplograptus fritschi Perner, 1895: A-C - NM L27520 (flattened rhabdosomes; C - holotype, A, B - syntypes on the same slab, specimen B figured by Prribyl (1949, pl. 3, fig. 8); D - WBM S 05152 (partial relief); E - WBM S 05151 (relief specimen, mostly exfoliated external mold). A-C from Králův Dvůr; D, E from Praha-Vršovice - Eden (construction site). All figures $\times 10$, scale bar equals $1 \mathrm{~mm}$.

1980 Glyptograptus ojsuensis sp. nov.; Koren’ \& Mikhaylova in Apollonov et al., pp. 143, 145, pl. 41, figs 1-8; pl. 42, figs 1, 2, text-fig. 43.

1983 Glyptograptus? ojsuensis Koren' \& Mikhaylova. Koren' \& Sobolevskaya in Koren' et al., pp. 142, 


\begin{tabular}{|c|c|c|c|c|c|c|c|c|c|c|}
\hline \multirow[t]{2}{*}{ Specimen No. } & \multirow[t]{2}{*}{ Figures } & \multicolumn{5}{|c|}{ W } & \multicolumn{4}{|c|}{ 2TRD } \\
\hline & & th1 & th 3 & th 5 & th10 & dist. max & th2 & th5 & th10 & dist. th \\
\hline WBM S 5153 & $7 \mathrm{~F}, 11 \mathrm{H}$ & 0.95 & 1.45 & 1.8 & 2.1 & 2.45 & 1.75 & 1.9 & 2.0 & 2.1 \\
\hline WBM S 5154 & - & - & 1.5 & 1.9 & 2.0 & $>2.0$ & 1.7 & 1.65 & 2.0 & - \\
\hline CGS PŠ 1163 & $7 \mathrm{~A}$ & - & - & - & - & 2.65 & - & - & - & 2.15 \\
\hline CGS PŠ 1162 & - & 1.2 & 1.6 & 1.75 & 2.0 & 2.2 & 1.55 & 1.6 & 2.0 & 1.9 \\
\hline CGS PŠ 1170 & $7 \mathrm{G}, 13 \mathrm{C}$ & 1.25 & 1.45 & 1.7 & 2.0 & - & 1.7 & 1.95 & 2.0 & - \\
\hline CGS PŠ 1167 & $7 \mathrm{~J}$ & 1.15 & 1.55 & 1.8 & - & - & 1.95 & - & - & - \\
\hline CGS PŠ 1168 & $7 \mathrm{E}, 13 \mathrm{D}$ & 1.35 & 1.85 & - & - & - & 1.9 & - & - & - \\
\hline CGS PŠ 1165 & $13 \mathrm{~K}$ & 1.25 & 1.45 & 1.85 & 2.1 & - & 1.8 & 1.95 & $\sim 2.15$ & - \\
\hline CGS PŠ 1172 (1) & $13 \mathrm{I}$ & $?$ & 1.6 & 1.85 & - & - & 1.6 & - & - & - \\
\hline CGS PŠ 1172 (2) & $13 \mathrm{~J}$ & 1.4 & 1.75 & 2.55 & 2.9 & 2.9 & 1.55 & 1.8 & 1.9 & 1.9 \\
\hline
\end{tabular}

Table 5. Metabolograptus ojsuensis (Koren'\& Mikhaylova in Apollonov et al., 1980). Dimensions of illustrated and other selected specimens (in $\mathrm{mm}$ ); W - width.
144, pl. 41, figs 7-12; pl. 52, figs 1-3; text-fig. 53a-и, л (поп к).

1983 Diplograptus bohemicus (Marek). - Wang et al., pl. 7, figs 1-3, 11.

1984 Diplograptus ojsuensis (Koren' \& Mikhaylova). Ni, p. 323, pl. 1, figs 13-14; pl. 2, figs 17-18.

1989 Glyptograptus cf. teres (Perner). - Štorch \& Mergl, pl. 4, fig. 2.

1989 Glyptograptus cf. ojsuensis Koren' \& Mikhaylova.Štorch, pp. 181-182, pl. 2, figs 1, 2, 6, 7, text-fig. 2A-D.

1993 Glyptograptus (?Glyptograptus) ojsuensis Koren' \& Mikhaylova. - Legrand, p. 37, pl. 1, figs a-e, text-fig. 2a-g.

1993 Diplograptus bohemicus (Marek). - Lin in Mu et al., p. 129 , pl. 21, figs $1-5$ (see for further reference on Chinese D. bohemicus).

1993 Diplograptus vicatus; Lin in Mu et al., p. 130, pl. 21, figs 8-11.

2002 Diplograptus ojsuensis (Koren' \& Mikhaylova). Mu et al., p. 512, pl. 148, figs 9, 10.

2002 Normalograptus bohemicus (Marek). - Mu et al., p. 695 , pl. 143 , fig. 16 ; pl. 159, fig. 6 .

2005 Normalograptus ojsuensis (Koren' \& Mikhaylova). Chen et al., pp. 264-265, pl. 1, figs 4-7; pl. 2, fig. 8; text-figs 9D, K, N, 10I.

2011 Normalograptus ojsuensis (Koren' \& Mikhaylova). Štorch et al., pp. 375-376, figs 27A-D, 28G-I, tab. 25.

2011 Normalograptus extraordinarius. - Mitchell et al., pl. 1, fig. 6 .
Holotype. - Mature specimen 11586/96 housed in CNIGR Museum in Saint Petersburg, Russian Federation from Ojsu Spring, Kazakhstan, section F-1053 (different label mentioned in the explanation of plates: F-1039d) designated and figured by Koren' \& Mikhaylova in Apollonov et al. (1980) on pl. 41, fig. 1.

Material. - About 50 specimens preserved either flattened or rarely with low relief. They were found solitary or clustered with other fossils. The latter case yielded most of the material, especially because of abundant occurrences at Zadní Třebaň where they are associated with shelly fossils such as trilobites (e.g. Mucronaspis), brachiopods, and ostracods.

Description. - Robust septate rhabdosome of rectangular cross section, commonly more than $20 \mathrm{~mm}$ long (maximum recorded $35.5 \mathrm{~mm}$ ); $0.95-1.45 \mathrm{~mm}$ wide at first pair of thecae, widens rapidly to $1.45-1.85 \mathrm{~mm}$ at th3 and 1.7-2.0 $\mathrm{mm}$ at th5 (with extreme value $2.55 \mathrm{~mm}$ ). Subsequently widens slowly to $2.0-2.1 \mathrm{~mm}$ at th10 (range: 1.7 and $2.9 \mathrm{~mm}$ ), and a maximum of $2.2-2.9 \mathrm{~mm}$ reached by $10^{\text {th }}$ pair or later (at $18^{\text {th }}$ pair in one specimen).

Sicula $1.8-2.3 \mathrm{~mm}$ long and $0.25-0.4 \mathrm{~mm}$ wide at aperture, furnished with $0.4-2.8 \mathrm{~mm}$ long virgella. Asymmetric proximal end of pattern $\mathrm{H}$ astogeny, composed of th $1^{1}$ growing $0.15-0.35 \mathrm{~mm}$ downward along ventral side of sicula, then sharply bent to $1.0-1.2 \mathrm{~mm}$ long upward growing portion. Crossing canal of th $1^{2}$ arises from latero-ventral region of sicula with its ventral wall situated just on the level of sicular aperture. Crossing canal

Figure 11. A, B, F, G - Dicellograptus laticeps Štorch, 1989: A - MCZ 196546 (proximal part of large rhabdosome in partial relief, mostly exfoliated external mold); B - FSCU 5169 (detail of proximal part in partial relief); F, G - MCZ 196547 (large rhabdosome preserved in relief, G - detail proximal part). $\bullet$ C - Styracograptus sp.: WBM S 05150 (full relief external mold proximally, becoming compressed distally; the image is left-right reversed to simulate a cast and facilitate interpretation of its proximal part in reverse view). $\bullet$ D - Paraplegmatograptus uniformis Mu in Wang, 1978: CGS PŠ 321, specimen figured by Štorch (1989, fig. 3B). $\bullet$ E - Anticostia teres (Perner, 1895): FSCU 5158 (periderm mostly exfoliated). $\bullet$ H - Phormograptus chuchlensis (Přibyl, 1949); NM L31783 (holotype). A, B, F, G from Králův Dvůr; C from Vráž - D5 highway exit 14 (lower in the slope); D from Liteň; E from Lejškov; H from Praha-Velká Chuchle. Black scale bars equal $1 \mathrm{~mm}$, white scale bar equals $10 \mathrm{~mm}$. 
Petr Kraft et al. • Graptolites of the Králův Dvůr Formation (mid Katian to earliest Hirnantian, Czech Republic)

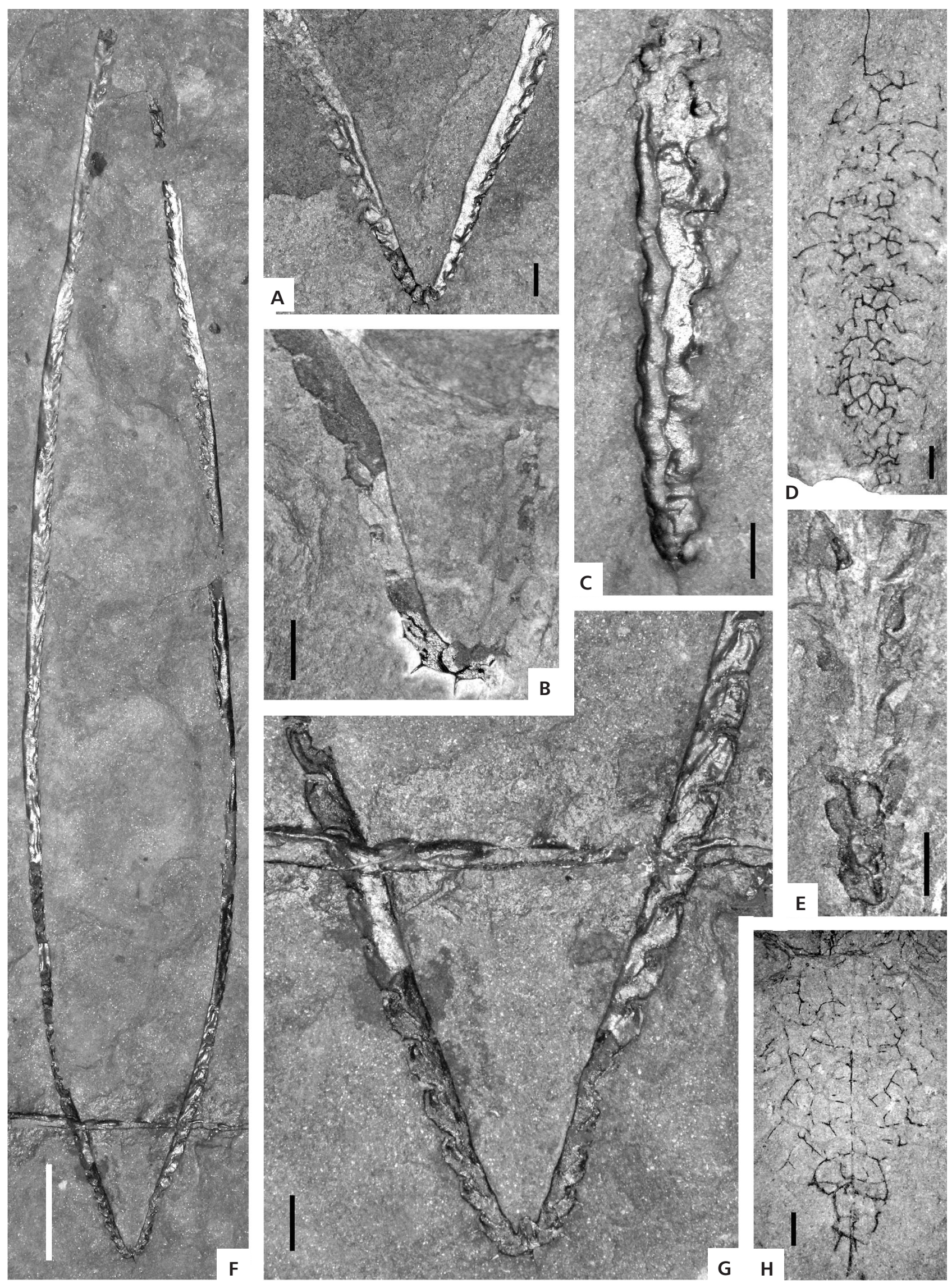




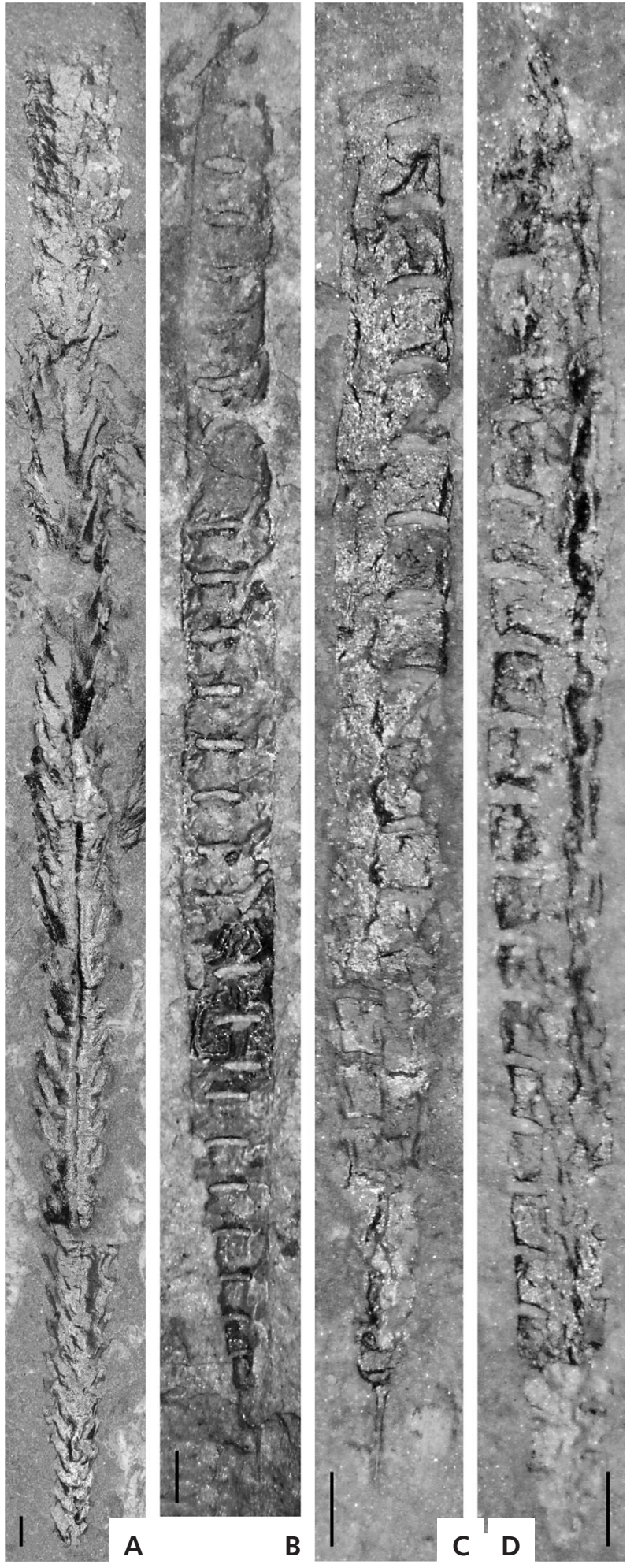

Figure 12. A - Diplograptus fritschi Perner, 1895: WBM S 05155 (mature rhabdosome preserved in low relief). $\bullet \mathrm{B}-\mathrm{D}-$ Styracograptus lobatus (Perner, 1895): B - NM L27532 (holotype, largely exfoliated scalariform specimen); C - WBM S 06567 (subscalariform flattened specimen); D - WBM S 06566 (low relief subscalariform specimen, with exfoliated proximal portion). A from Praha (probably Vršovice); B from Králův Dvůr; C, D from Svinaře. Scale bars equal $1 \mathrm{~mm}$. diverts to form prominent step with obtuse angle between its ventral wall and downward portion of th $1^{1}$. Dorsal wall of sicula exposed for $0.1-0.5 \mathrm{~mm}$ (Fig. 7F, J). Upward-growing metathecae of both th $1^{1}$ and $1^{2}$ straighten near their apertures. Length of th $1^{2}$ 0.7 to $1.0 \mathrm{~mm}$. Apertural widths of first thecae $\mathrm{ca}$ $0.25 \mathrm{~mm}$. Both th $1^{1}$ and $1^{2}$ diverge forming rather narrow proximal end.

Proximal 2-4 thecal pairs in flattened material strongly geniculate, nearly of climacograptid type. Subsequent 2-3 pairs change gradually to more rounded genicula of glyptograptid type which typify the reminder of the rhabdosome. Number of strongly geniculate thecae probably varies independent of influence of taphonomic effects. Infragenicular walls concave in profile. Supragenicular walls, 0.70 to $0.75 \mathrm{~mm}$ (exceptionally $0.6 \mathrm{~mm}$ ) long, straight or sligthly convex in distal part of rhabdosome. Ventral walls almost parallel to colony axis proximally (in climacograptid thecae) becoming markedly inclined in distal (glyptograptid) thecae. Thecal apertures 0.45 to $0.65 \mathrm{~mm}$ wide, subhorizontal. Distal thecae 1.9-2.2 $\mathrm{mm}$ long, overlapping for one half their length or slightly more. Thecae regularly alternate, 2TRD increases from 1.55 to $1.9 \mathrm{~mm}$ at th2, through 1.6 to $2.0 \mathrm{~mm}$ at th5 to $1.9-2.1 \mathrm{~mm}$ at th10 and $2.2-2.3 \mathrm{~mm}$ a little higher. Thecae number $10-11$ in $10 \mathrm{~mm}$ proximally.

Median septum complete, straight or slightly undulate begins at the second thecal pair as th $2^{1}$ is usually dicalycal, but exceptionally delayed, beginning at th5 in one specimen (Fig. 13K). Nema rather thick, projected well beyond the thecate part of the rhabdosome.

Remarks. - The rhabdosome dimensions of this species are quite variable. Considerable variation may be observed in many examined parameters of the rhabdosome, in particular the rhabdosome width, which varies with the degree of flattening. Nevertheless, the rhabdosome remains typically

Figure 13. A, E - Diplograptus fritschi Perner, 1895: A - WBM S 05152 (partial relief); E - WBM S 05151 (relief specimen, mostly exfoliated external mold). • B, F, G - Normalograptus angustus (Perner, 1895): B - NM L31797 (partial relief), specimen figured by Štorch (1989, fig. 2F); F - NM L31798 (partial relief, in part exfoliated external mold), figured by Přibyl (1949, pl. 2, fig. 9) and counterpart figured by Štorch (1989, fig. 2J); G - FSCU PK 28 (reverse proximal part in relief, distal part external mold). • C, D, H-K - Metabolograptus ojsuensis (Koren'\& Mikhaylova in Apollonov et al., 1980): C - CGS PŠ 1170 (low relief obverse view); D -CGS PŠ 1168 (partial relief reverse view, juvenile rhabdosome); H - WBM S 05153 (flattened, partly exfoliated rhabdosome); I - CGS PŠ 1172 (1) (flattened juvenile rhabdosome); J - CGS PŠ 1172 (2) (flattened mature specimen); K - CGS PŠ 1165 (relief specimen, reverse view). A, E from Praha-Vršovice; G from Liteň; B, F from Praha-Velká Chuchle; C, D, $\mathrm{H}-\mathrm{K}$ from Zadní Třebaň. All figures $\times 10$, except C, H, J × 6. Scale bars equal $1 \mathrm{~mm}$. 
Petr Kraft et al. • Graptolites of the Králův Dvůr Formation (mid Katian to earliest Hirnantian, Czech Republic)
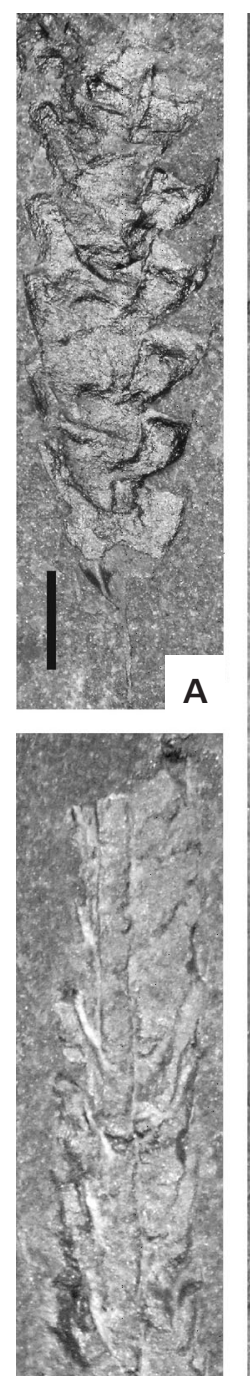
T. $\sin (x)$

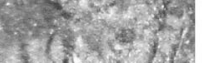
$15(1)$
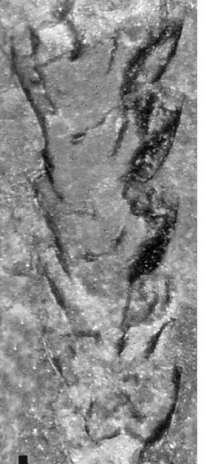

$1, x, 1$.

e. 010
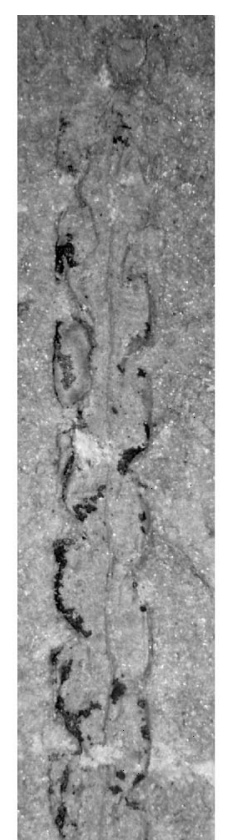

(4. $x^{4}=$
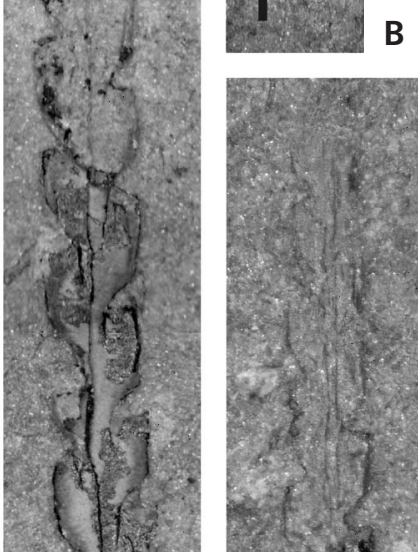

8)
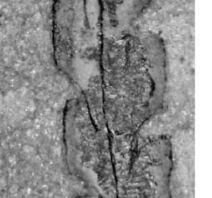

i)

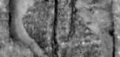

ale
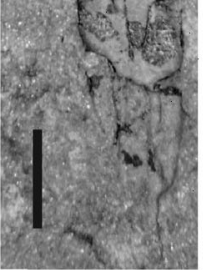

F
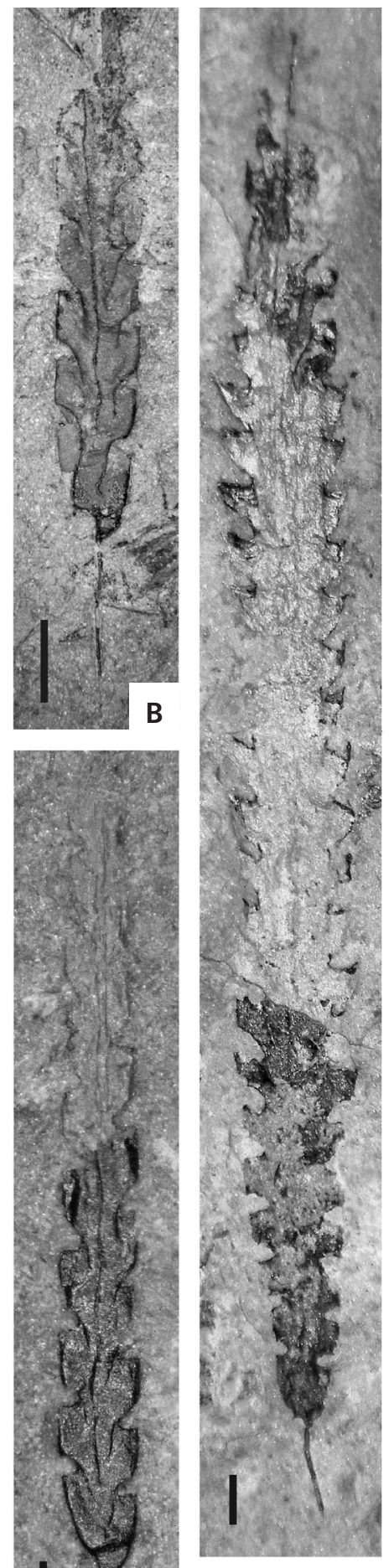

H

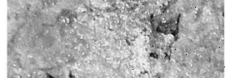

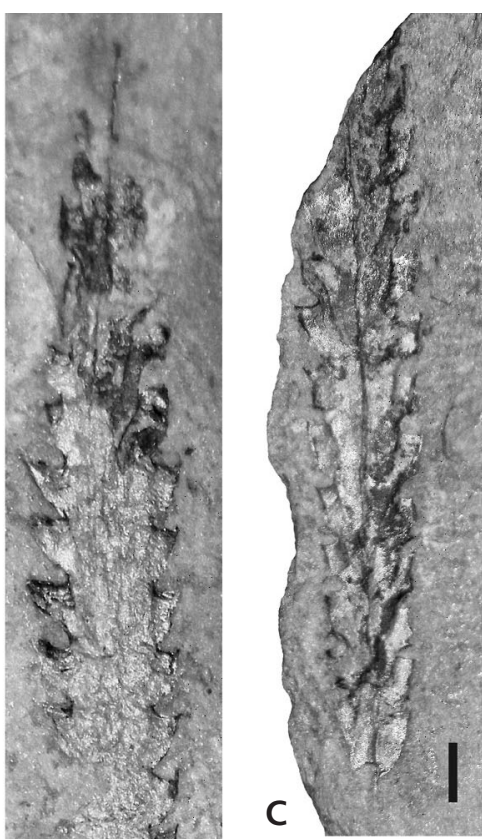
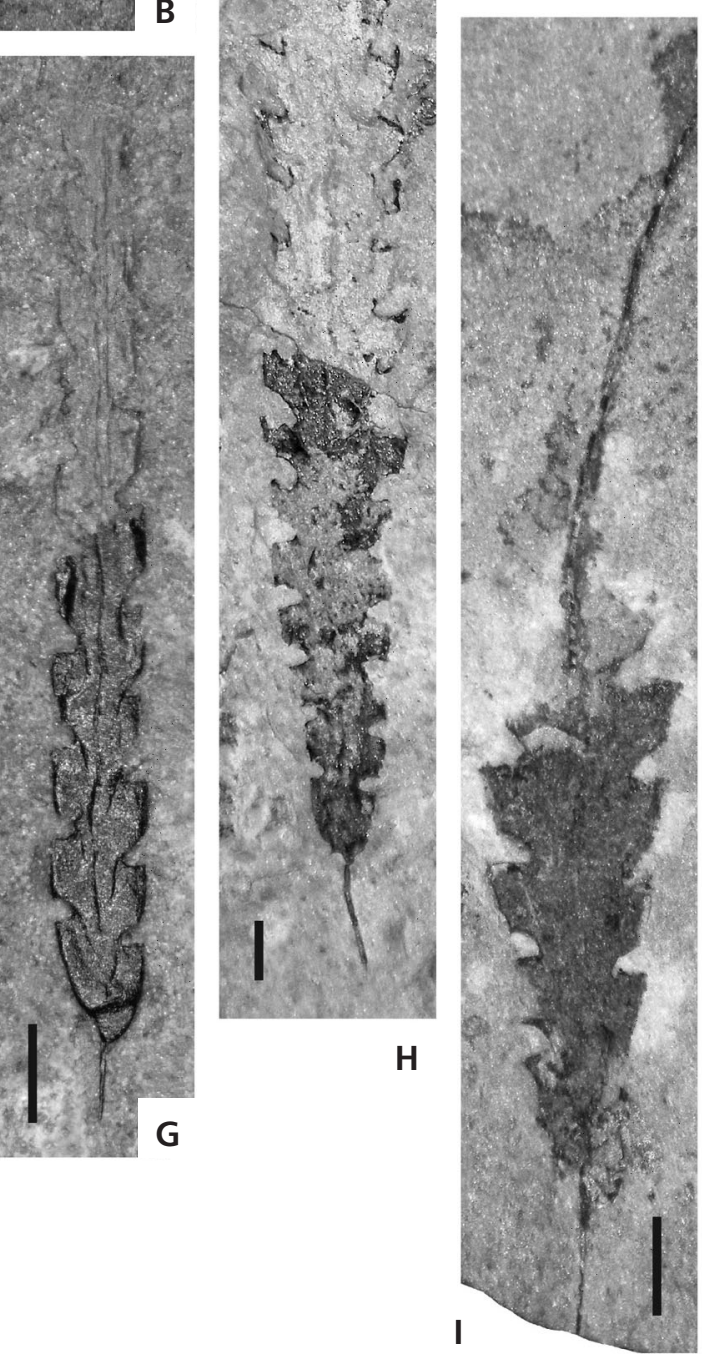
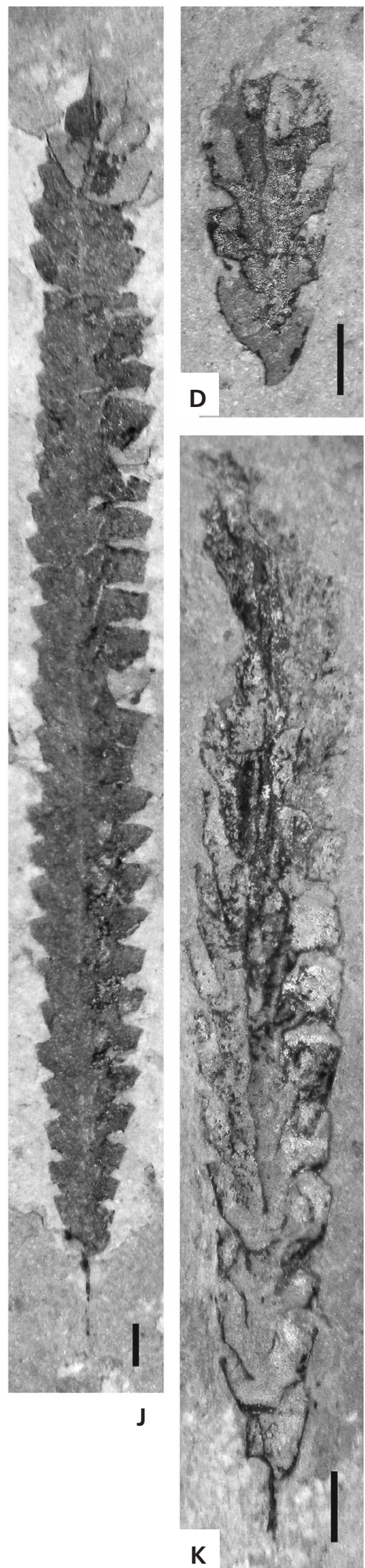
robust. The switch from climacograptid to glyptograptid profile in the proximal part of rhabdosome is typical and fits well the topotype material.

The close morphologic affinities of M. ojsuensis, Metabolograptus extraordinarius (Sobolevskaya, 1974) and Metabolograptus persculptus (Elles \& Wood, 1907) have been discussed in many papers. We refer to those of Koren' \& Mikhaylova in Apollonov et al. (1980), Štorch (1989) and Štorch et al. (2011). In this connection, it is worth noting that a few specimens (e.g., Fig. 13D, J) widen more rapidly than typical in M. ojsuensis and are distally wider. Mitchell et al. (2011) referred to one of these usually large specimens as M. extraordinarius. However, taking into account all measured specimens and continuous ranges of their biometric features, they appear to be extreme cases within the range of a single, unimodal population of M. ojsuensis specimens.

Occurrence. - Karlík, Liteň, Nesvačily, Praha-Zličín, Zadní Třebaň; uppermost part of the Králův Dvůr Formation. Cosmopolitan species reported from northern Gondwana (Bohemia, Niger), north-eastern Gondwana (Tibet), South China, Kazakhstania (southern Kazakhstan), Siberia (north-eastern Siberia), western Laurentia (Nevada, Arctic Canada) and eastern Laurentia (southern Scotland) as partly shown by the synonymy list above.

\section{Acknowledgements}

We appreciate detailed and helpful reviews by M.J. Melchin (St. Francis Xavier University, Antigonish), F. VandenBerg (Museum Victoria, Melbourne) and Zhang Yuandong (NIGPAS, Nanjing). We are grateful to our colleagues who helped us during our study of material housed in their institutions, especially V. Turek and M. Valent (National Museum, Prague), P. Budil (Czech Geological Survey, Prague) and J. Cundiff (Museum of Comparative Zoology, Harvard University, Cambridge, Massachusetts). This paper was funded by Grant Agency of Academy of Sciences of the Czech Republic through project IAA301110908 and by project PRVOUK P44 to P. Kraft as well as by a grant from the National Science Foundation (EAR 0958372) to C.E. Mitchell. This is contribution to the IGCP project No. 591 (The Early to Middle Paleozoic Revolution).

\section{References}

Ainsaar, L., Kaljo, D., Martma, T., Meidla, T., Männik, P., NõlvaK, J. \& Tinn, O. 2010. Middle and Upper Ordovician carbon isotope chemostratigraphy in Baltoscandia: A correlation standard and clues to environmental history. Palaeogeography, Palaeoclimatology, Palaeoecology 294(3-4), 189-201. DOI 10.1016/j.palaeo.2010.01.003

Apollonov, M.K., Bandaletov, S.M. \& Nikitin, J.F. 1980. The
Ordovician-Silurian Boundary in Kazakhstan. 232 pp. Nauka of Kazakh SSR, Alma-Ata. [in Russian]

Armstrong, H.A., Baldini, J., Challands, T.J., Gröcke, D.R. \& Owen, A.W. 2009. Response of the Inter-tropical Convergence Zone to Southern Hemisphere cooling during Upper Ordovician glaciation. Palaeogeography, Palaeoclimatology, Palaeoecology 284(3-4), 227-236. DOI 10.1016/j.palaeo.2009.10.001

Barrande, J. 1870. Défense des Colonies. 4. 186 pp. Prague, Paris.

Bergström, S.M., Chen Xu, Gutiérrez-Marco, J.C. \& Dronov, A. 2009. The new chronostratigraphic classification of the Ordovician System and its relations to major regional series and stages and to $\delta^{13} \mathrm{C}$ chemostratigraphy. Lethaia 42(1), 97-107. DOI 10.1111/j.1502-3931.2008.00136.x

BouČEK, B. 1928. O vrstvách zahořanských $-\mathrm{d}_{\varepsilon}$ českého ordoviku. Rozpravy České akademie věd a umění, Třída II (matematicko-přirodovědecká) 37, 33, 1-59. [in Czech; concurrent French version]

Brenchley, P.J. \& ŠToRCh, P. 1989. Environmental changes in the Hirnantian (upper Ordovician) of the Prague Basin, Czechoslovakia. Geological Journal 24(3), 165-181.

DOI 10.1002/gj.3350240302

Brussa, E.D., Toro, B.A., Mitchell, C.E. \& Astini, R.A. 2003. Biostratigraphic remarks on the Late Ordovician graptolite fauna from the area around Estancia Canota, 53-57. In Albanesi, G.L., Beresi, M.S. \& Peralta, S.H. (eds) Ordovician from the Andes. INSUGEO, Serie Correlación Geológica 17. 549 pp. Consejo Nacional de Investigaciones Científicas y Técnicas, Facultad de Ciencias Naturalles e Instituto Miguel Lillo, Universidad Nacional de Tucumán, Tucuman.

Bruvo, M. 2005. Graptolitzoneringen i Dicellograptus Skifern (Øvre Ordovicium) på Bornholm, Danmark. 105 pp. MSc. thesis, University of Copenhagen.

Budil, P., Fatka, O., Kolár̆, P. \& David, M. 2011a. Arthrorhachis Hawle \& Corda, 1847 (Agnostida) in the Prague Basin (Barrandian area, Czech Republic) revisited. Bulletin of Geosciences 86(4), 707-724. DOI 10.3140/bull.geosci.1262

Budil, P., Fatka, O., Mergl, M. \& David, M. 2011b. Trilobite biostratigraphy of the Králův Dvůr Formation (upper Katian, Prague Basin, Czech Republic): global faunal changes or facies-related distribution? Geologické výzkumy na Moravě a ve Slezsku 18(1), 4-10.

CARRuthers, W. 1867. Graptolites: their structure and systematic position. Intellectual Observer 11(4), 10(5), 64, 65.

Chen Xu, Fan Jun-Xuan, Melchin, M.J. \& Mitchell, C.E. 2005. Hirnantian (late Ordovician) graptolites from the Upper Yangtze Region, China. Palaeontology 48, 235-280. DOI 10.1111/j.1475-4983.2005.00453.x

Chen Xu, Rong Jia-Yu, Fan Jun-Xuan, Zhan Ren-bin, Mitchell, C.E., Harper, D.A.T., Melchin, M.J., Peng Ping'an, Finney, S.C. \& WANG XIAO-FENG 2006. The Global Boundary Stratotype Section and Point (GSSP) for the base of the Hirnantian Stage (the uppermost of the Ordovician System). Episodes 29(3), 183-196.

Chen Xu, Rong Jia-Yu, Mitchell, C.E., Harper, D.A.T., Fan Jun-Xuan, Zhan Ren-Bin, Zhang Yuan-dong, Li Rong-Yu \& WANG YI 2000. Late Ordovician to earliest Silurian graptolite and brachiopod biozonation from the Yangtze region, South China, with a global correlation. Geological Magazine 137(6), 623-650. 
CHLuPÁČ, I. 1951a. Stratigrafické poměry králodvorských břidlic u Karlíka a Zadní Třebáně. Věstník Ústředního ústavu geologického 26, 194-212. [in Czech with Russian and English summary]

CHLuPÁČ, I. 1951b. Profil králodvorskými břidlicemi (Ashgillian) u Velké Chuchle. Věstník Královské české společnosti nauk, Tř́da matematicko-prrírodovědecká 1950(1), 1-10. [in Czech with English summary]

CHLuPÁč, I. 1953. Poznámky ke stratigrafii králodvorských břidlic v okolí Litně. Časopis Národního musea, Oddíl př́rodovědný 122, 28-33. [in Czech]

Chlupáč, I., HavlíčEK, V., KŘíž, J., Kukal, Z. \& ŠTorch, P. 1992. Palaeozoikum Barrandienu (kambrium - devon). 292 pp. Vydavatelství Českého geologického ústavu, Praha. [in Czech]

Chlupáč, I., Havlíček, V., KŘíž, J., Kukal, Z. \& Štorch, P. 1998. Palaeozoic of the Barrandian (Cambrian to Devonian). 183 pp. Czech Geological Survey, Prague.

CoOper, R.A. \& Fortey, R.A. 1982. The Ordovician Graptolites of Spitsbergen. Bulletin of the British Museum of Natural History, Geology Series 36(3), 157-302.

Cooper, R.A. \& Sadler, P.M. 2012. The Ordovician Period. With a contribution from Hammer, Ø. \& Gradstein, F.M., 489-523. In Gradstein, F.M., OGg, J.G., Schmitz, M.D. \& OGG, G.M. (eds) The Geological Timescale 2012, Volume 1. 1176 pp. Elsevier B.V., Amsterdam.

DAviES, K.A. 1929. Notes on the graptolite fauna of the Upper Ordovician and Lower Silurian. Geological Magazine 66, 1-27. DOI 10.1017/S0016756800099763

Elles, G.L. \& Wood, E.M.R. 1906. A monograph of British graptolites. Part 5. Monograph of the Palaeontographical Society 60(288), 1xxiii-xcvi, 181-216.

Elles, G.L. \& Wood, E.M.R. 1907. A monograph of British graptolites. Part 6. Monograph of the Palaeontographical Society 61(297), xcvii-cxx, 217-272.

Elles, G.L. \& Wood, E.M.R. 1908. A monograph of British graptolites. Part 7. Monograph of the Palaeontographical Society 62(305), cxxi-cxlviii, 273-358.

ForTEY, R.A. \& CocKs, L.R.M. 2005. Late Ordovician global warming - The Boda event. Geology 33(5), 405-408. DOI 10.1130/G21180.1

ForTEY, R.A. \& COOPER, R.A. 1986. A phylogenetic classification of the graptoloids. Palaeontology 29(4), 631-654.

FreCh, F. 1897. Lethaea Geognostica. Lethaea Paleozoica 1, 11, Graptolithen. Schweizerbart, Stuttgart.

Goldman, D. \& Bergström, S.M. 1997. Late Ordovician graptolites from the North American midcontinent. Palaeontology 40(4), 965-1010.

Goldman, D., Mitchell, C.E., Melchin, M.J., Fan Jun-Xuan, Wu SHUANG-YE \& SHEETs, D.H. 2011. Biogeography and mass extinction: extirpation and re-invasion of Normalograptus species (Graptolithina) in the Late Ordovician palaeotropics. Proceedings of the Yorkshire Geological Society 58, 227-246.

GuRLEY, R.R. 1896. North American graptolites: new species and vertical range. Journal of Geology 4, 63-102. DOI $10.1086 / 607425$

Gutiérrez-Marco, J.C., Robardet, M., Rábano, I., Sarmiento, G.N., San José Lancha, M.Á., Herranz Araújo, P. \& Pieren Pidal, A.P. 2002. Ordovician, 31-49. In GibBons, W. \&
Moreno, T. (eds) The Geology of Spain. 649 pp. Geological Society, London.

HadDing, A., 1915. Der Mittlere Dicellograptus-Schiefer auf Bornholm. Lunds Universitets Arsskrift, Afd. 2, 11(4), 1-40.

HALl, J. 1865. Graptolites of the Quebec group. Figures and descriptions of Canadian organic remains. Decade II. 151 pp. Geological Survey of Canada, Ottawa.

HAVLí̌EK, V. 1981. Development of a linear sedimentary depression exemplified by the Prague Basin (Ordovician-Middle Devonian; Barrandian area - central Bohemia). Sborník geologických věd, Geologie 35, 7-48.

Havlí̌̌EK, V. 1982. Ordovician in Bohemia: development of the Prague Basin and its benthic communities. Sborník geologických věd, Geologie 37, 103-136.

HAVLíčEK, V. 1989. Climatic changes and development of benthic communities through the Mediterranean Ordovician. Sborník geologických věd, Geologie 44, 79-116.

HAVlíčEK, V. \& MAREK, L. 1973. Bohemian Ordovician and its international correlation. Časopis pro mineralogii a geologii 18(3), 225-232.

HAVlíčEK, V. \& VANĚK, J. 1966. The Biostratigraphy of the Ordovician of Bohemia. Sborník geologických věd, $\breve{R} a d a P-$ Paleontologie 8, 7-67.

Hisinger, W. 1837. Lethaea Suecica seu Petrificata Sueciae, Supplementum 1. 124 pp. Norstedt, Stockholm.

Hopkinson, J. 1871. On Dicellograptus, a new species of Graptolites. Geological Magazine 8, 20-26.

DOI 10.1017/S001675680016087X

Hopkinson, J. \& LAPworth, J. 1875. Descriptions of the graptolites of the Arenig and Landeilo rocks of St. David's. Quarterly Jounal of the Geological Society of London 31, 631-672. DOI 10.1144/GSL.JGS.1875.031.01-04.49

JACKSON, D.E. 1971. Development of Glyptograptus hudsoni sp. nov. from Southampton island, North-West Territories, Canada. Palaeontology 14(3), 478-486.

Kaljo, D., Männik, P., Martma, T. \& Nõlvak, J. 2012. More about the Ordovician-Silurian transition beds at Mirny Creek, Omulev Mountains, NE Russia: carbon isotopes and conodonts. Estonian Journal of Earth Sciences 61(4), 277-294. DOI 10.3176/earth.2012.4.07

Koren', T.N., Oradovskaya, M.M., Pylma, L.J., Sobolevs Kaya, R.F. \& ChugaeVA, M.N. 1983. The Ordovician and Silurian Boundary in the Northeast of USSR. 205 pp. Nauka Publishers, Leningrad. [in Russian with English abstract]

LaPorte, D.F., Holmden, C., Patterson, W.P., Loxton, J.D., Melchin, M.J. \& Mitchell, C.E. 2009. Local and global perspectives on carbon and nitrogen cycling during the Hirnantian glaciation. Palaeogeography, Palaeoclimatology, Palaeoecology 276, 182-195.

DOI 10.1016/j.palaeo.2009.03.009

LAPWORTH, C. 1873. Notes on the British graptolites and their allies I. On an improved classification of the Rhabdophora. Geological Magazine 1(10), 500-504, 555-560.

DOI 10.1017/S0016756800469256

LAPWORTH, C. 1876. The Silurian System in the south of Scotland, 1-28. In Armstrong, J., Young, J. \& Robertson, D. (eds) Catalogue of Western Scottish Fossils. 164 pp. Blackie and Son, Glasgow.

Lapworth, C. 1877. On the graptolites of County Down. Pro- 
ceedings of the Belfast Naturalists' Field Club, 1876-1877, $125-148$.

LAPWORTH, C. 1879. On the geological distribution of the Rhabdopleura. Annals and Magazine of Natural History, Series 5(3), 245-257, 449-455; (4) 333-341, 423-431.

LAPWORTh, C. 1880. The Silurian sequence of Rhayader. Quarterly Journal of the Geological Society of London 56, 67-137. DOI 10.1144/GSL.JGS.1900.056.01-04.09

Legrand, P. 1977. Contribution à l'étude des graptolites du Llandoverien inferieur de l'Oued In Djerane (Tassili N'ajjer oriental, Sahara algérien). Bulletin de la Société d'Histoire Naturelle de l'Afrique du Nord 67, 141-196.

Legrand, P. 1987. Modo de desarrollo del suborden Diplograptina (Graptolithina) en el Ordovício superior y en el Silúrico. Implicaciones taxonómicas. Revista Española de Paleontologia 2, 59-64.

LEGRAND, P. 1993. Graptolites d'àge ashgillien dans la region de Chirfa (Djado, République du Niger). Bulletin du Centres Recherches Exploration-Production Elf Aquitaine 17, 435-442.

LEGRAND, P. 2011. On the Katian/Hirnantian boundary. application on the north-African border of Gondwana, 287-294. In Gutiérrez-Marco, J.C., Rábano, I. \& García-Bellido, D. (eds) Ordovician of the World. Cuadernos del Museo Geominero 14. 679 pp. Instituto Geológico y Minero de España, Madrid.

LI JI-JIN 1984. Graptolites from the Xinling Formation (Upper Ordovician) of South Anhui. Memoirs of Nanjing Institute of Geology and Palaeontology, Academia Sinica 20, $145-194$.

Li Ji-JiN \& CHENG HAN-JUN 1988. Graptolites from Nancheng Formation at Liangshan, Hanzhong of Shaanxi. Acta Palaeontologica Sinica 27(2), 164-178.

LoydeLl, D.K. 2007. Graptolites from the Upper Ordovician and Lower Silurian of Jordan. Special Papers in Palaeontology 78, $1-66$.

Maletz, J., Carlucci, J. \& Mitchell, C.E. 2009. Graptoloid cladistics, taxonomy and phylogeny. Bulletin of Geosciences 84(1), 7-19. DOI 10.3140/bull.geosci.1108

Marr, J.E. 1880. On the Predevonian rocks of Bohemia. Quarterly Journal of the Geological Society 36, 591-619. DOI 10.1144/GSL.JGS.1880.036.01-04.44

McCoy, F. 1850. On some new genera and species of Silurian Radiata in the collection of the University of Cambridge. Annals and Magazine of Natural History 6, 270-290.

Melchin, M.J., Mitchell, C.E., Holmden, C. \& Štorch, P. 2013. Environmental changes in the Late Ordovician - early Silurian: Review and new insights from black shales and nitrogen isotopes. The Geological Society of America Bulletin 125(11/12), 1635-1670. DOI 10.1130/B30812.1

Melchin, M.J., Mitchell, C.E., NACZK-CAmeron, A., Fan Jun-XUAN \& LoXton, J. 2011. Phylogeny and adaptive radiation of the Neograptina (Graptoloida) during the Hirnantian mass extinction and Silurian recovery. Proceedings of the Yorkshire Geological Society 58(4), 281-309.

Mergl, M. 2011a. Earliest occurrence of the Hirnantia Fauna in the Prague Basin (Czech Republic). Bulletin of Geosciences 86(1), 63-70. DOI 10.3140/bull.geosci.1245

Mergl, M. 2011b. Faunal turnover near the Katian/Hirnantian boundary in the Prague Basin (Czech Republic), 359-366. In Gutiérrez-Marco, J.C., Rábano, I. \& García-Bellido, D. (eds) Ordovician of the World. Cuadernos del Museo Geominero 14. 679 pp. Instituto Geológico y Minero de España, Madrid.

MikhaYlova, N.F. 1973. Graptolity verkhnego ordovika i nizhnego silura Kazakhstana, 14-19. In IvanovskiY, A.B. (ed.) Novoye v paleontologii Sibiri i Sredney Azii. 140 pp. Nauka, Novosibirsk. [in Russian]

Mitchell, C.E. 1987. Evolution and phylogenetic classification of the Diplograptacea. Palaeontology 30, 353-405.

Mitchell, C.E., Goldman, D., Klosterman, S.L., Maletz, J., SheEts, H.D. \& Melchin, M.J. 2007. Phylogeny of the Ordovician Diplograptoidea, 332-339. In Li JUN, FAN JUN-XUAN \& Percival, I. (eds) Proceedings of the $10^{\text {th }}$ International Symposium of the Ordovician System, Nanjing, China, June 2007. Acta Palaeontologica Polonica 46 (Supplement).

Mitchell, C.E., Maletz, J. \& Goldman, D. 2009. What is Diplograptus? Bulletin of Geosciences 84(1), 27-34. DOI 10.3140/bull.geosci.1109

Mitchell, C.E., Štorch, P., Holmden, C., Melchin, M.J. \& GutiérReZ-MARCo, J.C. 2011. New stable isotope data and fossils from the Hirnantian Stage in Bohemia and Spain: implications for correlation and paleoclimate, 371-378. In Gutiérrez-Marco, J.C., Rábano, I. \& García-Bellido, D. (eds) Ordovician of the World. Cuadernos del Museo Geominero 14. 679 pp. Instituto Geológico y Minero de España, Madrid.

Mu EN-ZHi 1949. Two growth patterns of Climacograptus. Geological Review 14(4-6),185-188 [in Chinese].

Mu EN-ZHI 1963. Research in graptolite faunas of Chilianshan. Scientia Sinica 12(3), 347-371.

Mu En-Zhi, Li Ji-Jin, Ge Mei-Yu, Chen Xu, Lin YaO-Kun \& Ni YU-NAN 1993. Upper Ordovician graptolites of Central China Region. Palaeontologia Sinica, New Series B, 189(29), 1-393. [in Chinese with English summary]

Mu En-Zhi, Li Ji-Jin, Ge Mei-Yu, Lin YaO-Kun \& Ni Yu-nan 2002. Graptolites of China. 1205 pp. Science Press, Beijing. [in Chinese]

Mu EN-ZHI \& LiN YAO-KUN 1984. Graptolites from the Ordovician-Silurian boundary sections of Yichang area, S. Hubei, 45-73. In Nanjing Institute of Geology and Palaeontology, ACAdemia Sinica (ed.) Stratigraphy and palaeontology of systematic boundaries in China, Ordovician-Silurian boundary 1. 516 pp. Anhui Science and Technology Publishing House, Hefei.

Ni YU-NAN 1984. Upper Ordovician graptolites from Baoshan, western Yunnan. Acta Palaeontologica Sinica 22, 320-327. [in Chinese with English summary]

Nicholson, H.A. 1867. On some fossils from the Lower Silurian rocks of south of Scotland. Geological Magazine 4(33), 107-113. DOI 10.1017/S0016756800205293

Oвuт, A.M. 1955. Graptolity, 136-139. In NiKiforova, O.I. (ed.) Polevoy atlas ordovikskoy $i$ silurskoy fauny Sibirskoy platformy. Gosgeoltechizdat, Moskva. [in Russian]

Oвut, A.M. \& Sennikov, N.V. 1985. Osobennosti llandoveriyskikh planktonovykh soobschestv Sibirskoy platformy, 51-60. In Betekhtina, O.A. \& Zhuravleva, I.T. (eds) Sreda $i$ zhizn'v geologicheskom proshlom (Paleobasseyny $i$ ich 
obivateli). Trudy Instituta geologii i geofyziki 628. 137 pp. Nauka, Novosibirsk. [in Russian]

OBut, A.M. \& SobolevsKaya, R.F. 1974. Graptolites, 85-159. In Palaeozoic reference sections of the North-East USSR. Nauka, Magadan.

Page, A.A., Zalasiewicz, J.A., Williams, M. \& Popov, L.E. 2007. Were transgressive black shales a negative feedback modulating glacioeustasy in the Early Palaeozoic Icehouse?, 123-156. In Williams, M., Haywood, A.M., Gregory, F.J. \& Schmidt, D.N. (eds) Deep-Time Perspectives on Climate Change: Marrying the Signal from Computer Models and Biological Proxies. The Micropalaeontological Society, Special Publications. 589 pp. The Geological Society, London.

Perner, J. 1895. Études sur les Graptolites de Bohême, II ième Partie. Monographie des Graptolites de l'Étage D. 31 pp. Raimond Gerhard, Leipsic, Prague.

PřıBYL, A. 1949. Revise českých ordovických diplograptidů a glossograptidů. Rozpravy České akademie věd a umění, Tř́ída II 59, 1, 1-48. [in Czech]

RickARDS, R.B. 2002. The graptolitic age of the type Ashgill Series (Ordovician), Cumbria, UK. Proceedings of the Yorkshire Geological Society 54(1), 1-16.

Ross, R.B. \& BerRY, W.B.N. 1963. Ordovician graptolites of the Basin Ranges in California, Nevada, Utah and Idaho. U.S. Geological Survey Bulletin 1134, 1-177.

Ruedemann, R. 1908. Graptolites of New York, Part 2. Graptolites of higher beds. Memoirs of the New York State Museum of Natural History, Albany 11, 457-583.

Ruedemann, R. 1925. The Utica and Lorraine Formations of New York, Pt. II: Systematic Paleontology 1 (Plants, Sponges, Corals, Graptolites, Crionoids, Worms, Bryozoans, Brachiopods). New York State Museum Bulletin 262, 1-171.

SHAw, F.C. 2000. Trilobites of the Králův Dvůr Formation (Ordovician) of the Prague Basin, Czech Republic. Bulletin of the Czech Geological Survey 75(4), 371-404.

SkogLund, R. 1963. Uppermost Viruan and Lower Harjuan (Ordovician) stratigraphy of Västergötland and Lower Harjuan graptolite fauna of central Sweden. Bulletin of Geological Institutions of the University Uppsala 42, 1-55.

SobolevskayA, R.F. 1974. New Ashgill graptolites in the middle flow basin of the Kolyma River, 63-71. In Oвut, A.M. (ed.) Graptolites of the USSR. 160 pp. Nauka, Novosibirsk. [in Russian]

Sobolevskaya, R.F. 2011. Atlas of the Paleozoic fauna of Taimyr. Part II. The Ordovician and Silurian graptolites. Trudy NIIGA-VNIIOkeanologia 221. 281 pp. FGUP VIINOkeanologia im. I.S. Gramberga, Sankt-Peterburg. [in Russian]

Stewart, S. \& Mitchell, C.E. 1997. Anticostia, a distinctive new Late Ordovician "glyptograptid" (Diplograptacea, Graptoloidea) based on three-dimensionally preserved specimens from Anticosti Island, Quebec. Canadian Journal of Earth Sciences 34, 215-228. DOI 10.1139/e17-018

ŠтоRсн, P. 1989. Late Ordovician graptolites from the upper part of the Králův Dvůr Formation of the Prague Basin (Barrandian, Bohemia). Věstník Ústředního ústavu geologického 64(3), 173-186.

Štorch, P. \& Mergl, M. 1989. Králodvor/Kosov boundary and the late Ordovician environmental changes in the Prague Basin (Barrandian area, Bohemia). Sborník geologických věd, Geologie 44, 117-153.

Štorch, P., Mitchell, C.E., Finney, S.C. \& Melchin, M.J. 2011. Uppermost Ordovician (upper Katian-Hirnantian) graptolites of north-central Nevada, U.S.A. Bulletin of Geosciences 86(2), 301-386. DOI 10.3140/bull.geosci.1264

Štorch, P. \& Serpagli, E. 1993. Lower Silurian Graptolites from Southwestern Sardinia. Bolletino della Società Paleontologica Italiana 32, 3-57.

VAndenbroucke, T., Rickards, R.B. \& Verniers, J. 2005. Upper Ordovician chitinozoan biostratigraphy from the type Ashgill area (Cautley district) and the Push Gill section (Dufton district, Cross Fell Inlier), Cumbria, Northern England. Geological Magazine 142(6), 783-807. DOI 10.1017/S0016756805000944

WANG Ju-DE 1974. Graptolites, 731-736. In Yunnan Bureau of Geology (ed.) Fossil Atlas of Yunnan, Part 1. Peoples Publishing House of Yunnan, Kunming. [in Chinese]

Wang XIAO-FEng 1978. Ordovician Graptolites, 192-210. In Stratigraphy Research Group of the Yangtze Gorges, Hubei Bureau of Geology (ed.) Sinian to Permian stratigraphy and palaeontology of eastern Yangtze Gorges. 381 pp. Geological Publishing House, Beijing. [in Chinese]

Wang Xiao-feng, Zeng Qing-luan, Zhou Tian-mei, Ni Shi-ZhaO, Xu Guang-Hong, Sun QuAn-ying, Li Zhi-Hong, XiAng Li-wen \& LAI CAI-GEN 1983. Latest Ordovician and earliest Silurian faunas from the eastern Yangtze Gorges, China with comments on Ordovician-Silurian boundary. Bulletin of Yichang Institute of Geology and Mineral Resources, Chinese Academy of Geological Sciences 6, 126-196.

Whittington, H.B. 1955. Additional new Ordovician graptolites and a chitinozoan from Oklahoma. Journal of Paleontology 29, 837-851.

Williams, S.H. 1981. Form and mode of life of Dicellograptus (Graptolithina). Geological Magazine 118, 401-408. DOI 10.1017/S0016756800032271

WiLLIAMS, S.H. 1982. The late Ordovician graptolite fauna of the Anceps Bands at Dob's Linn, southern Scotland. Geologica et Palaeontologica 16, 29-56.

Zalasiewicz, J.A., TAYlor, L., Rushton, W.A., Loydell, D.K., RickARDS, R.B. \& Williams, M. 2009. Graptolites in British stratigraphy. Geological Magazine 146, 785-850.

DOI 10.1017/S0016756809990434 